Rhode Island College

Digital Commons @ RIC

\title{
Ambulatory Oncology Nurses' and Nurse Practitioners' Self Perception of Competence in Cancer Survivorship Care
}

Tracy Lynn Carraggi

Follow this and additional works at: https://digitalcommons.ric.edu/etd

Part of the Nursing Commons

\section{Recommended Citation}

Carraggi, Tracy Lynn, "Ambulatory Oncology Nurses' and Nurse Practitioners' Self Perception of Competence in Cancer Survivorship Care" (2019). Master's Theses, Dissertations, Graduate Research and Major Papers Overview. 298.

https://digitalcommons.ric.edu/etd/298

This Major Paper is brought to you for free and open access by the Master's Theses, Dissertations, Graduate Research and Major Papers at Digital Commons @ RIC. It has been accepted for inclusion in Master's Theses, Dissertations, Graduate Research and Major Papers Overview by an authorized administrator of Digital Commons @ RIC. For more information, please contact digitalcommons@ric.edu. 


\title{
AMBULATORY ONCOLOGY NURSES' AND NURSE PRACTITIONERS' SELF PERCEPTION OF COMPETENCE IN CANCER SURVIVORSHIP CARE
}

\author{
by \\ Tracy Lynn Carraggi \\ A Major Paper Submitted in Partial Fulfillment \\ of the Requirements for the Degree of \\ Master of Science in Nursing \\ in \\ The School of Nursing \\ Rhode Island College
}

2019 


\begin{abstract}
The advances in cancer research with medical treatments and early detection practices have improved the survival of cancer patients as they are living longer and the rate of cancer survivors are increasing steadily. Cancer survivors may experience residual side effects from cancer or its treatment. These side effects may be disabling acutely or long-term causing physical and psychological effects that can negatively affect quality of life. There is a need for extended follow-up care for cancer survivors beyond solely just receiving treatment for cancer. Nurses and nurse practitioners can make a huge impact on the quality of life for cancer survivors by providing education, symptom management, promoting healthy lifestyles, preventative care, emotional support, and cancer surveillance. Research has shown that knowledge and competence in cancer survivorship care exist. The purpose of this project was to examine oncology nurses and nurse practitioner's self-perception of competence in cancer survivorship care. A survey questionnaire "Caring for patients living with and beyond cancer competency tool" was administered to nurses and nurse practitioners at the outpatient oncology institute. The survey measured self-perception of competence in the areas of clinical practice, symptom management, care coordination, and proactive management. Twenty-nine participants $(n=29)$, twenty-five nurses and four nurse practitioners completed the survey. Results indicated self-perception of knowledge deficits in certain areas of cancer survivorship care. The findings support the need for continuing education and training to give nurses and nurse practitioners the knowledge and skills to care for a growing population of cancer survivors.
\end{abstract}




\section{Acknowledgements}

I want to thank my family for their sacrifice these past years for letting me accomplish my dream in obtaining my master's degree; it is finally coming to an end. I foremost want to thank so many individuals who have supported me along the way to get this far in accomplishing my first major research project. To Professor Dame, my first reader, who has guided and helped me from day one with this project, I want to thank her so much. To Kara Misto, Director of MSN program at Rhode Island College for being my principal investigator and Maria Ducharme, senior vice president, patient care services, chief nursing officer at The Miriam Hospital for being my chairperson for both of your support with IRB. I also want to thank my second reader Julia Twining, advanced practice manager at the Miriam Hospital, and my third reader Megan Begnoche, nursing quality and safety manager for Lifespan cancer institute. To Laura Butterfield, director of Lifespan cancer institute at the Miriam Hospital site for her support in allowing this research project to be done at the site. Without everyone's support, I would not be where I am at today, thank you once again. 


\section{Table of Contents}

Background/Statement of the Problem ................................................................... 1

Literature Review........................................................................................ 4

Theoretical Framework ................................................................................. 21

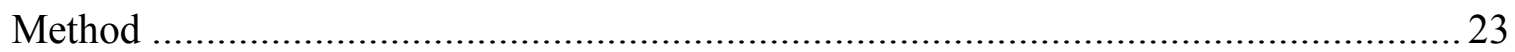

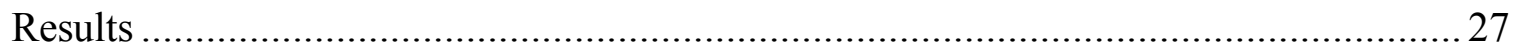

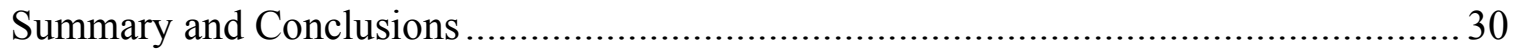

Recommendations and Implications for Advanced Nursing Practice .......................... 34

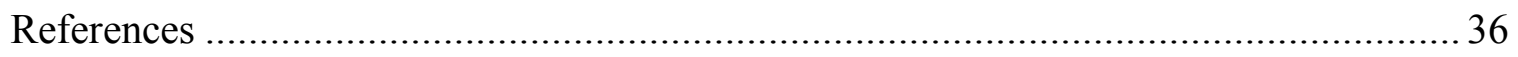

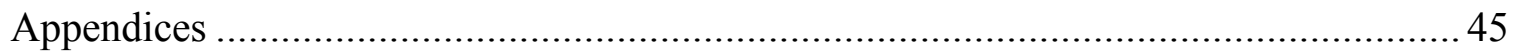


Ambulatory Oncology Nurses' and Nurse Practitioners' Self Perception of of Competence in Cancer Survivorship Care

\section{Background/Statement of the Problem}

Many years ago, a cancer diagnosis was considered a death sentence, however the advances in medical research for the treatment and early detection of cancer have improved the survival of patients and there is a growing number of cancer survivors today (Weaver, Jessup, \& Mayer, 2013). The National Cancer Institute (NCI) estimated, in the United States (U.S.), there are 15.5 million cancer survivors. By the year 2026, it is projected to increase to 20.3 million survivors and as a result, cancer survivorship care has emerged as a top priority in the medical field of oncology (NCI, 2016).

A cancer survivor is an individual with a history of cancer. Cancer survivorship is a personal health journey that begins when diagnosed with cancer and continues throughout the disease process until death. Cancer survivorship has two common definitions. The first definition is there is no evidence of cancer after treatment, and the second is to be living with, through, and beyond cancer in which treatment continues over an extended period of time to reduce the risk of recurrence, or managing chronic symptoms (American Society of Clinical Oncology, 2016a).

Cancer survivors may experience residual side effects from chemotherapy treatments. These side effects may be disabling acutely or long-term causing physical and psychological effects that can negatively affect the quality of life. Side effects can begin during treatment and persist long after the completion of treatment. In addition, there may be delayed effects of cancer treatment that may not appear until many years later. Problems that can affect the quality of life among cancer survivors are physical 
changes and may include an altered self-body image, which can occur with a mastectomy from breast cancer or a permanent colostomy from colon cancer. Medical problems such as cardiac toxicity from chemotherapy medications can occur (Morgan, 2009). Cancer survivors may experience adverse physical side effects of chronic pain, peripheral neuropathies, and chronic fatigue. Psychological changes may develop with cognitive memory impairment due to certain chemotherapy medications creating an inability to concentrate and is referred to as "chemo brain." Anxiety and stress may exist from a constant fear of cancer recurrence, uncertainty of the future, and the financial burden of having cancer. The out of pocket expenses for treatment and a lack of social support may also contribute to anxiety and stress (Watts, 2011). Living a good quality of life is just as important as survival rates, and therefore, there is a need for extended follow-up care for cancer survivors beyond solely receiving medical treatment.

Nurses and nurse practitioners can play an important role in improving the quality of life of cancer survivors, as the goal is to provide high-quality care to improve cancer survivors quality of life. Cancer survivors can lead healthy active lives with the guidance of nurses and nurse practitioners by promoting healthy lifestyles, providing education, emotional support, preventative care, and cancer surveillance. Cancer survivorship involves many complex aspects of care and cancer survivors need to receive competent care. 
Nurses and nurse practitioners may be aware of general survivorship care although may not have all the knowledge and competent skills to meet the unique needs of cancer survivors (Palos \& Zandstra, 2013). Therefore, the purpose of this project will be to examine ambulatory oncology nurses' and nurse practitioners' self-perception of competence in cancer survivorship care.

Next, the literature review will be presented. 


\section{Literature Review}

A literature search was conducted using PubMed, CINAHL, and Medline databases. Keywords searched were: cancer, chemotherapy, side effects of cancer treatment, cancer survivor, quality of life, cancer survivorship care, nurse selfcompetence of cancer survivorship care. Keywords were searched alone and in combination. Years searched were from 1985 to 2018. Relevant literature starting from 1985 was included to explain the historical era of cancer survivorship.

\section{Cancer}

Cancer is a group of many types of malignant diseases that can start anywhere in the body growing and spreading in different ways. Cancer cells first develop from a genetic mutation in a single cell growing out of control (NCI, 2015b). This abnormal growth continues to divide uncontrollably crowding out normal cells and eventually forming growths, which are known as tumors. Cancer cells can metastasize to distant sites establishing new tumors called secondary cancers (American Cancer Society [ACS], 2015). Different types of cancers are classified according to the tissue or blood cells of origin.

A major risk factor for cancer is aging, and with the baby boomer population and people living longer, cancer rates are steadily increasing. Genetics, exposure to chemical and physical carcinogens such as tobacco, poor diet intake, obesity, physical inactivity, ultraviolet rays, asbestos, and exposure to viruses are all risk factors for cancer. The NCI estimates, in 2018, there will be 1,735,350 new cases of cancer in the U.S. (NCI, 2018). Cancer is considered a chronic medical condition that may cause many delayed or late side effects from the disease itself or treatment (Zebrack, 2000). Controlling cancer and 
destroying abnormal cells without trying to damage healthy cells requires a range of treatments, including chemotherapy.

\section{Chemotherapy}

The purpose of chemotherapy medications is to cause cancer cell death or to slow cancer cell growth over time. Chemotherapy is a systemic anti-cancer therapy administered throughout the body and into the bloodstream. Chemotherapy is toxic and can have toxic effects on normal tissue. Overall, chemotherapy can be used to cure cancers, control cancer growth, and/or for palliative measures to ease symptoms by shrinking a tumor to relieve a symptom such as pain (NCI, 2015a). Other treatment options are surgery or radiation, although these therapies only work on a targeted cancer area. Systemic intravenous chemotherapy treats tumors but also attacks cancer cells that have circulated to other parts of the body, which is called metastasis (far away from the original cancer tumor site) (ACS, 2016). There are also other types of chemotherapy: intrathecal chemotherapy that is administered into the fluid between the membranes tissues that line the brain and spinal cord. Intraperitoneal a chemotherapy technique that delivers chemotherapy drugs directly into the abdominal cavity through a tube that is surgically placed and intravesical chemotherapy is when chemotherapy drugs are put directly into the bladder via a urinary catheter. Consequently, chemotherapy can create acute, late, or long-term side effects, which can affect quality of life. 


\section{Side Effects of Cancer Treatment}

There are many acute, late and chronic side effects cancer survivors may experience over their lifetime that will decrease their quality of life. Ultimately, cancer survivors may experience multiple symptoms at the same time, and as a result of cancer and its treatment, symptoms can last for many years. It is essential to understand cancer survivors' quality of life, the impact, and the factors that contribute to it. There is a need to have extended follow-up care beyond cancer treatment. The most common sideeffects cancer survivors experience are fatigue, chronic pain, neuropathy, and cognitive deficits.

Fatigue. Fatigue is one of the most severe symptoms cancer survivors experience. De Raaf, De Klerk, Timman, Hinz and Van der Rijt (2012) described cancer patients fatigue as a chronic, distressing, unpleasant emotional and cognitive exhaustion that caused tiredness throughout the day creating a negative impact on daily activities. Many cancer survivors do not recover from fatigue after cancer treatment and fatigue can persist for many years. Goedendorp, Gielissen, Verhagen and Bleijenberg (2013) reported nearly a quarter of cancer survivors suffered from severe fatigue in the first year after cancer treatment and did not recover.

Chronic Pain. Pain is a widespread problem among cancer survivors. In certain subpopulations of cancer patients, such as breast cancer survivors, the prevalence of pain is much higher with more than $30 \%$ of breast cancer survivors reporting above average pain levels greater than ten years after treatment (Forsythe et al., 2013; Glare et al., 2014). Breast cancer survivors can experience persistent post-surgical syndrome pain, lymphedema, neuropathy, plexopathies from radiation therapy, and arthralgias from 
hormonal therapy (Glare et al., 2014). Cancer-related pain threatens the health and quality of life of many cancer survivors and interferes with activities of daily living. Cancer survivors' pain differs from the general population due to identifiable clinical factors contributing to the pain such as tissue damage and invasiveness of a tumor (Glare et al., 2014). Green, Hart-Johnson, and Loeffler (2011) reported 60-85\% with advanced cancer, and nearly $40 \%$ of long-term five-year cancer survivors described having pain that affected their daily life. Pain becomes a short-term acute problem during the initial treatment phase of cancer but can become a chronic problem that may last a lifetime.

Chemotherapy Induced Neuropathy. Neuropathy is an early or late major side effect of chemotherapy. Cancer survivors can experience painful symptoms along with decreased sensations with light touch and temperature. Neuropathy can also produce decreased muscle strength, upper and lower extremity dysfunction and problems with ataxia, balance and coordination. Chemotherapy-induced neuropathy can be severe and extend for many years beyond chemotherapy completion. Miaskowski et al. (2017) conducted a study of 426 cancer survivors. Participants completed a questionnaire and reported areas on the body where they experienced chronic neuropathy symptoms. Participants experienced neuropathy in the upper extremities (4.9\%), lower extremities (27\%), and both the upper and lower extremities (68.1\%).

Chemotherapy Cognitive Impairment. Cognitive changes are a significant side effect of chemotherapy. Chemotherapy-induced cognitive impairment (CICI), which is also known as "chemo-brain" affects cancer survivors concentration, learning, reasoning, and memory adversely compromising the quality of life of survivors with solid cancerous tumors. The growing number of long-term survivors who may have to cope with 
cognitive changes is escalating. Unfortunately, even small doses of chemotherapy can penetrate the blood-brain barrier causing cell death and decreased cell division resulting in neurotoxic damage to the central nervous system. Argyriou, Assimakopoulos, Iconomou, Giannakopoulou and Kalofonos (2011) reported CICI is a relatively common underdiagnosed side effect and management of these symptoms are not occurring in patients.

Cardiac Toxicity. Cardiac toxicity contributes to heart problems with cancer survivors. Cardiotoxicity refers to heart damage because of chemotherapy treatment. Chemotherapy medications associated with cardiotoxicity are anthracyclines, cyclophosphamide, and trastuzumab. With cardiac toxicity, there are late cardiac effects of cardiac dysfunction, congestive heart failure, atherosclerosis, thromboembolism, pericarditis, and an increased risk of developing hypertension (Lenihan \& Cardinale, 2012).

\section{Anxiety and Fear of Cancer Recurrence}

Sarkar et al. (2015) surveyed 335 cancer patients and investigated the relationship among anxiety and fear of cancer recurrence and supportive care needs. There were 123 women and 212 men who completed the self-reported Fear of Progression Questionnaire, the General Anxiety Disorder Scale, and the Supportive Care Needs Survey. Sarkar et al. (2015) reported $3.9 \%$ of patients were classified as having high anxiety, and $5.1 \%$ had a high fear of cancer recurrence. Psychological and the fear of cancer recurrence was the highest unmet social supportive care need. Lebel, Tomei, Feldstain, Beattie, and McCallum (2013) reported the utilization of emergency room visits, frequent outpatient ambulatory care visits, and an increased amount of medication use was reported by 
cancer survivors who had a higher fear of recurrence. The authors also reported high levels of anxiety and fear of cancer recurrence correlated with cancer patients having higher unmet supportive care needs (Lebel et al., 2013; Sakar et al., 2015). Untreated distress experienced by a cancer survivor contributes to poor quality of life and interdisciplinary survivorship supportive care services are needed.

\section{Financial Hardship}

Financial hardship with ongoing and residual medical bills is a struggle for cancer survivors. The excessive cost of cancer treatments, including high-priced cancer medications with large co-pays, can cause financial distress among cancer survivors especially if there is time off of work due to treatments and side effects. Additionally, depleted bank accounts and inadequate support for financial resources to offset the cost of medical treatments can cause distress. Oncology chemotherapy medications account

for the largest spending of any medical specialty in the U.S. and the average price of an anti-cancer drug exceeds over $\$ 100,000$ per year (Prasad, De Jesus, \& Mailankody, 2017).

Altice, Banegas, Tucker-Seeley, and Yabroff (2017) conducted a systematic review to identify the financial hardships experienced by cancer survivors. Forty-five studies were included in the review. Researchers found $12 \%$ to $62 \%$ of survivors reported being in debt due to cancer treatments and $47 \%-49 \%$ of cancer survivors experienced psychological and financial distress. In addition, $4 \%-45 \%$ of cancer survivors did not adhere to recommended cancer treatments by either skipping medications or avoiding filling prescriptions because of cost. Furthermore, cancer 
survivors have greater out of pocket costs if there is continued late or lasting treatment effects from chemotherapy or cancer itself.

Bernard, Farr, and Fang (2011) conducted a study using data collected from the 2001 to 2008 Medical Expenditure Panel Survey. A national representative sample of 4,243 cancer survivors who received treatment for cancer were included. The study examined out of pocket medical spending, defining high health care burden spending that was more than $20 \%$ of income for healthcare. The researchers found $13.4 \%$ of cancer survivors had high annual out of pocket expenses in the thousands of dollars, compared to $9.7 \%$ with only chronic medical conditions and $4.4 \%$ without chronic conditions.

A research study conducted by Fenn et al. (2014) used data from the 2010 National Health Interview Survey (NHIS). The sample size consisted of 2,108 cancer survivors. A multivariable regression model was used to examine the relationship between cancer, financial problems, and quality of life. Researchers reported cancer survivors who had extensive financial problems $(8.6 \%)$ were more likely to rate their physical and mental health poor compared to those with no financial issues $(69.6 \%)$.

\section{Health Promotion}

Cancer survivors are at risk for adverse health conditions from obesity, lack of physical activity, and smoking. Lifestyle modifications can have positive effects on a cancer survivors' health, and scientific evidence indicates physical activity, a healthy weight, and good nutrition habits decrease the incidence of cancer recurrence (Geller, Vacek, Flynn, Lord, \& Cranmer, 2014). Cancer survivors require health promotion, education, and guidance for healthy lifestyle behaviors. Cancer survivors need education on regular health screenings, avoiding tobacco products, moderation with alcohol intake, 
sun protection, nutrition, and stress management for the prevention of recurrence or secondary cancers.

\section{Definition of a Cancer Survivor}

The term cancer survivor began in the U.S. and was used to advocate and promote research and care for a growing vulnerable population (Khan, Rose, \& Evans, 2011). The actual definition of cancer survivor varies among people with a history of cancer as it may be based on one's own experiences, concerns, and beliefs with cancer. Many organizations have their preference as well on the definition of a cancer survivor. The Centers for Disease Control and Prevention (CDC) defines a cancer survivor as an individual with a diagnosis of cancer through the balance of life (Wronski, 2015). The National Coalition for Cancer Survivorship (NCCS) defines a cancer survivor as "someone with cancer from the moment of diagnosis through the end of life no matter if the cancer is cured, in active treatment, or palliative including family members, caregivers, and friends affected by the diagnosis of cancer" (NCCS 1995, p.3). The NCI (2015c) refers to a cancer survivor as a person who has a history of cancer from the time

of diagnosis and continues to live life to overcome a serious, life-threatening disease until death.

\section{Definition of Cancer Survivorship}

Cancer Survivorship is defined as the process of living life after being diagnosed with cancer regardless of how long survival is before death with the understanding of looking at the "whole person; a holistic approach" to the physical well-being, social, psychological including spirituality that may be impacted by cancer (Zebrack 2000, p. 239). Areas of cancer survivorship are health, symptoms of cancer and its treatment, 
ability to function in daily life, lifestyle, and well-being. Cancer survivorship covers all aspects of care beyond the diagnosis of cancer and phases of treatment (Zebrack, 2000). The real challenge of cancer survivorship is to live the best as you can and for as long as you can, as some survivors continue to receive treatment to prevent recurrence and management of the disease (NCCS, 2014).

The concept of survivorship as stages of survival came into existence in the mid1980s when a medical physician by the name of Fitzhugh Mullan, who was diagnosed and living with cancer, wrote a seminal memoir called "Seasons of Survival." Mullan (1985) was the first to describe the three seasons/phases of survivorship. Mullan promoted awareness of cancer and the challenges cancer survivors faced. In 1986, Mullan and a group of cancer survivors and oncology professionals began the cancer survivorship campaign and founded the NCCS. This organizations' mission is to advocate for quality cancer care for all people who have cancer. The NCCS campaign on cancer survivorship has had a positive influence on changing society's use of the term “cancer victim” to “cancer survivor" (Mayer, Nasso, \& Earp, 2017).

\section{Phases of Cancer Survivorship Cancer}

There are three phases of cancer survivorship care: the acute, extended, and permanent phase. The acute phase begins when a person is diagnosed with cancer and the primary focus is treatment along with managing any acute side effects. The extended phase begins at the end of cancer treatment with remission and continued treatment for any side effects. In this stage, surveillance begins by monitoring for any new recurrence or the developments of late effects of treatment. Lastly, the permanent phase represents 
an unlikely chance for any cancer returning after many years and the priority is managing any long-term side effects of cancer treatment (Mullen, 1985).

Standards for Cancer Survivorship Care. Cancer survivorship care begins at the very beginning of a cancer survivor being diagnosed with cancer and continues throughout life. Survivorship care involves helping cancer survivors maintain a high quality of life. A cancer survivorship program with a multidisciplinary approach, consisting of oncologists, oncology nurses and nurse practitioners, radiation oncologists, plastic surgeons, surgical oncologists, pathologist, PCP, social work, pharmacists, registered dietitian, and rehab and palliative care providers, helps to ensure effective medical care, education, and emotional support for a cancer survivor (National Cancer Survivorship Resource Center, 2012). Nurse practitioners and nurses can assist with improving cancer survivors' quality of life by conducting patient assessments and implementing education and treatment management.

In 2000, The Institute of Medicine (IOM) composed a report titled "From Cancer Patient to Cancer Survivor: Lost in Transition" and included guidelines and recommendations to improve cancer survivors' healthcare and quality of life. This report discussed the long-term risks of cancer survivors. The goals were to raise awareness of the medical, functional, and psychosocial problems that may result from cancer and its treatment with interventions to achieve a high quality of care (Hewitt, Greenfield, \& Stovall, 2006). The report proposed that the major essential components of survivorship care are prevention, surveillance, intervention, and coordination. Prevention includes promoting healthy behaviors, monitoring for recurrent and new secondary cancers and other late adverse side effects of cancer treatment. The IOM recommends surveillance 
for cancer and proposes interventions for any medical, physical, psychological or social problems. Lastly, interdisciplinary care coordination needs to take place to ensure all needs are met, and survivorship care plans need to be provided at the end of treatment to the cancer survivor (Hewitt et al., 2006).

\section{Survivorship Care Plans}

A cancer survivorship care plan which details the treatment summary and followup care enables cancer survivors to receive optimal health care. The purpose of the survivorship care plan is to help patients keep a record of their cancer history and should be shared and serve as a communication tool for PCP's and other healthcare providers. It is provided once a patient transitions off active treatment. Survivorship care plans contain a detailed personalized history of the patient's cancer and treatment, information on the potential long-term adverse effects of cancer and its treatment, recommendation for surveillance, cancer screening, preventative health promotion, and follow-up care. Survivorship care plans consist of recommendations for referrals and resources for any physical and psychosocial needs (Hewitt et al., 2006). In addition, survivorship care plans are an educational tool for cancer survivors to keep as a reference that will aid in leading and maintaining healthier lifestyles by promoting and supporting health. There are also treatment care plans while a patient is actively on chemotherapy treatment to prevent recurrence or for symptom management.

\section{Models of Cancer Survivorship Care Delivery}

There are several models of survivorship care delivery. The disease specific-model consists of a collaboration with a physician and nurse practitioner who specialize in one cancer disease such as breast, prostate, lung, colon, or any blood cancer such as leukemia, 
lymphoma, multiple myeloma (Corcoran, Dunne, \& McCabe, 2015). The

multidisciplinary model is when cancer survivor care needs are met in one visit with multiple providers such as a social worker and physical therapist along with the oncologist and nurse practitioner. The independent visit model is a consultative visit allowing the nurse practitioner to provide an independent one-time survivorship visit while continued follow-up visits remain with the oncologist (Corcoran et al., 2015). The integrated nurse practitioner visit is designed to meet the follow-up needs of cancer survivors. A general survivorship clinic provides survivorship services for all cancer groups. The community generalist model focus is on wellness for a cancer survivor rather than disease and promotes self-independence (American Society of Clinical Oncology, 2016b; Corcoran et al., 2015).

\section{Cancer Survivorship Care}

Cancer survivorship care is essential to the health and wellness of cancer survivors. Geller et al. (2014) sought to identify the needs of adult cancer survivors 60 years and older with a cross-sectional descriptive research study. A convenience sample consisted of 1668 survivors who experienced survivorship greater than five years. The survivors' unmet needs (CaSun) survey instrument was administered to participants. This survey consists of fifty-three specific needs with questions in the domains of access to care, health services, information on cancer, side effects, emotional, social, economic, legal issues, and spiritual aspects of care (Geller et al., 2014). Results revealed $30.2 \%$ of survivors had one unmet need for the emotional, social, and spiritual domain, and $14.4 \%$ had one unmet need in the economic and legal domain. Further results showed $14.8 \%$ of 
survivors unmet needs included not receiving help to reduce stress, and information on possible late and long-term adverse side-effects of treatment (Geller et al., 2014).

\section{Knowledge and Competence}

Knowledge refers to information gained from education, books, guidelines, protocols of care, and experience (Christensen, 2011). Competence encompasses both knowledge and the necessary skills to perform a specific task and the standards of performance to provide quality care (Sinha, 2018). In 1998, a report called Strengthening Consumer Protection: Priorities for Health Care Workforce Regulation by the Pew Health Professions Commission Taskforce states "ensuring competence of healthcare professionals throughout their careers is a persistent challenge to both public and private sectors" (Finocchio, Dower, Blick, \& Gragnola, 1998 p. ii).

Volker, Watson, Becket, and Scott (2011) administered a self-identified learning needs assessment survey to assess statewide cancer related educational needs of licensed nurses throughout the state of Texas across all practice settings. The sample consisted of 521 nurses, $28 \%$ were staff nurses, $19 \%$ were supervisory nurses, $17 \%$ were faculty educators, and $61 \%$ were advanced practice nurses within practice areas of oncology, geriatrics, medical-surgical, home health, public health, hospice, and schools of nursing. Results varied between oncology and non-oncology nurses. Top educational needs were pain management for oncology nurses $42 \%$ versus $54 \%$ non-oncology nurses and with skin cancer $30 \%$ oncology nurses versus $45 \%$ non-oncology nurses. Several priority areas for educational needs were survivorship issues, health promotion strategies for smoking cessation and education on clinical trials. Time constraints were reported by both oncology and non-oncology nurses to be the greatest barrier to obtaining additional 
cancer-related education to integrate cancer-related knowledge and skills into practice. The researchers reported nurses who participated in the survey valued knowing about cancer care but may not be representative of all Texas nurses wanting to learn more about cancer. Volker et al. (2011) advised with the growing number of cancer survivors; all nurses regardless of specialty area experience must have the current knowledge and skills to provide competent cancer care. The researchers propose the findings from the survey could help guide educational programs and approaches for ongoing educational services that will promote the delivery of competent cancer care.

Irwin, Klemp, Glennon, \& Frazier (2011) agree that all health care providers, not just oncology professionals, need skills and education in providing cancer survivorship care as cancer survivors are cared for in all healthcare settings. The authors administered a survey to gather information regarding survivorship care from the perspectives of oncology nurses related to services provided, barriers to survivorship care, and survivorship practices. The sample size consisted of 399 oncology nursing society members with at least one year of experience in caring for cancer survivors. Survey results revealed $49 \%$ of oncology nurses with less than five years of experience in nursing, reported they lacked sufficient knowledge in survivorship care compared to $36 \%$ of nurses with more than five years experience. In addition, Irwin et al. (2011) reported the greatest barrier to delivering survivorship care were lack of time and no survivorship program was available for cancer survivors as only $27 \%$ of nurses had a formal survivorship program in their place of employment. According to the researchers, there was a need for further education to enhance the knowledge and skills of nurses who will provide survivorship care. 
Klemp, Frazier, Glennon, Trenecek, and Irwin (2011) conducted a study that explored nurses' self-reported knowledge and educational needs and preferred methods of learning. Nurses reported being knowledgable on topics of fatigue, anxiety, fear of cancer recurrence and less knowledgeable on financial issues, employment, and insurance discrimination. Klemp et al. (2011) also revealed nurses prefer online learning to meet reported continuing education needs on the topics of late and long-term physical effects of cancer and its treatment, managing emotional issues, cancer screening, and complementary and alternative therapies for cancer survivorship. According to the researchers, self-reported knowledge creates positive changes by increasing awareness for developing quality continuing education to help nurses develop and maintain competency in cancer survivorship care.

Lester, Wessels, and Jung (2014) sought to identify knowledge gaps that could guide education endeavors to advance nurses knowledge and enhance survivorship care planning. Previous research studies (Irwin et al., 2011; Klemp et al., 2011; Volker et al., 2011) revealed educational gaps in lack of knowledge with aspects of cancer survivorship care. Lester et al. (2014) conducted a descriptive cross-sectional study at a Midwestern comprehensive cancer center. Two hundred twenty-three registered and advanced practice nurses participated and completed a self-report online questionnaire on their knowledge of cancer survivorship care. Nurses reported knowing healthy lifestyle habits and more than $50 \%$ of nurses reported knowledge of chemotherapy and its side effect of fatigue, weight gain from hormonal therapy, radiation therapy, surgery, and depression. Less than $50 \%$ of nurses reported having less knowledge on the impact of cancer on the family, biologic cancer agents, lymphedema from breast cancer surgery, and osteoporosis 
prevention. Less than $40 \%$ of nurses reported knowing side-effects of bone marrow transplant and employment issues for cancer survivors. Only 25\% of nurses knew genetics risks and financial issues. Survey results revealed gaps in cancer survivorship knowledge that are evident and consistent with previous studies. According to Lester et al. (2014), experienced older nurses were correct more frequently in their survey responses about the components of survivorship care plans when compared to younger less experienced nurses. Researchers affirm fragmented survivorship care will continue to exist unless focused education on cancer survivorship issues is provided (Lester et al., 2014).

Faithfull, Samuel, Lemanska, Warnock, and Greenfield (2016) examined the selfreported perceptions of competence in nurses and allied professionals who provided survivorship care, in the United Kingdom. The sample consisted of 368 nurses and 250 allied health professionals who cared for cancer survivors one-year post-cancer treatment in both primary oncology and community settings. Participants received a selfassessment questionnaire, titled "Caring for Patients Living With and Beyond Cancer," which evaluates caring for cancer survivors in four domains of care; clinical practice, symptom management, care coordination and proactive management. Participants perceptions of learning needs were included in the questionnaire. Participants reported deficits in long-term medication management, care planning, complex symptom management especially cardiac toxicity, care coordination, and proactive care health promotion. Community nurses reported they had fewer skills to care for cancer survivors. Respondents expressed the need for more educational training on the longterm health effects of cancer treatments, psychosocial care, self-management techniques 
for patient education and health rehabilitation. Nurses, as well as allied health care professionals, reported needing to receive training and education in survivorship was a high priority. The researchers expressed views that perceptions of skills do not reflect the actual competence of practitioners and it is imperative to use a framework of competence to evaluate and guide education with skill development for standardization and quality improvement (Faithfull et al., 2016).

When combined, the prior mentioned research studies support there is a continued pattern of self-reported perceptions of educational needs with cancer survivorship care. Studies suggest there is a need for expanded continuing education with oncology nurses and nurse practitioners to increase clinical expertise skills and knowledge to provide cancer survivors with safe, high-quality care.

Upon conducting a literature review, there is a lack of research on the topic of competence involving nurses or nurse practitioners and survivorship care. The competence of healthcare professionals is of interest for this project, therefore, confirming the need to examine ambulatory oncology nurses' and nurse practitioners' self-perception of competence in cancer survivorship care.

Next, the theoretical framework will be discussed. 


\section{Theoretical Framework}

The Nursing Role Effectiveness Model, a middle range theory, developed by Irvine, Sidani, \& McGillis Hall (1998) is the conceptual framework that will guide this project. The conceptual model was based on theorist Donabedian's (1987) model of quality of care. The concepts of the Nursing Role Effectiveness Model will be applied to this project to examine nurses and nurse practitioners self-perception of competence in cancer survivorship care.

Irvine et al. (1998) created the Nursing Role Effectiveness Model to examine nursing-sensitive patient outcomes for quality improvement. This conceptual model examines nurses' contribution to health care based on specific relationships between structure, process, and outcome variables. This type of framework serves a purpose for cancer survivorship by examining nursing-sensitive patient outcomes of survivorship care for cancer survivors relating the structure, process, and outcomes by nurses and nurse practitioners for quality improvement. As the healthcare industry researches evidence for the quality of care patients are receiving, the responsibility of being competent with healthcare providers is intensifying (Irvin et al., 1998). This model of care describes structural variables which influence the nursing process that affects patient outcomes. Irvin et al.'s (1998) model of care identifies the contribution of nurses' roles to outcome achievements in quality patient care. The structural components of this framework consist of nursing, patient, and organizational variables that influence the outcomes of healthcare that will be applied to this project. The Nursing Role Effectiveness Model's framework has three major concepts which are structure, nurses roles, and patient health outcomes. The first major concept structure has three subcomponents which are nursing 
(knowledge, experience, and skills), organizational (assignment pattern and workload), and patient (health status and severity). Nursing variables that can influence the quality of nursing care are knowledge and competent skills in caring for cancer survivors. The organizational component applied in this project will be the model of delivery of cancer survivorship care delivered to cancer survivors at the Lifespan Cancer Institute that the nurses and nurse practitioners must follow. The second concept is the nursing role consisting of independent, dependent, and interdependent role function; which will guide this project with nurses and nurse practitioners clinical role with caring for cancer survivors and their self-perception of competence. Lastly, the third concept of patient health outcomes will be the associated variable with nurses and nurse practitioners selfperception competency level and their point of view with current knowledge to improve health outcomes, quality of life in caring for cancer survivors.

The Nursing Role Effectiveness Model was chosen to guide this project to explain the relationships between the components of nursing, nursing care practice, and patient outcomes. Furthermore, this framework will guide this project as oncology nurses and nurse practitioners who specialize in oncology care have specific roles in caring for cancer survivors and are concerned with caring, promoting comfort, restoring health, health promotion, education, and preventing illness. A competent, caring nursing relationship with cancer survivors can have a positive impact on improving the quality of life of cancer survivors.

Next, the methods section will be presented. 


\section{Method}

\section{Purpose}

The purpose of this project was to examine ambulatory oncology nurses' and nurse practitioners' self-perception of competence in cancer survivorship care.

\section{Research Question}

The research question investigated was: What are ambulatory oncology nurses and nurse practitioners self-perception of competence in cancer survivorship care?

\section{Design}

The design of this project was a descriptive questionnaire which measured selfperception of competence. An adapted online questionnaire "Caring for Patients Living With and Beyond Cancer Competence Tool" was administered. De-identified data were collected using the Research Electronic Data Capture (REDCap) site at Lifespan.

REDCap is a secure web-based application designed to support data capture and protect sensitive participant information. Questionnaire data were collected anonymously through REDCap.

\section{Sample}

The population sample included ambulatory oncology nurses and nurse practitioners with at least one year of experience providing direct patient care to cancer survivor patients at the Lifespan Cancer Institute. The Lifespan Cancer Institute at the TMH site employs six nurse practitioners and twenty-three registered nurses. 


\section{Site}

The Lifespan Cancer Institute is a 4 site cancer program with one site being the outpatient ambulatory center located at the Miriam Hospital with twenty-three RN's working as chemotherapy infusion, navigators, triage, and research nurses and six nurse practitioners. This site provides the most current cancer diagnosis and treatment options. The Lifespan Cancer Institute is an active clinical trial site instituting the most updated protocols and treatments and offers comprehensive cancer care. The cancer center has 29 available chairs and five-bed rooms between two treatment areas to treat cancer patients.

\section{Procedures}

Permission was obtained by the Miriam Hospital Institutional Review Board (IRB) (Appendix A) and the Rhode Island College (RIC) IRB to conduct this project (Appendix B). An informational letter was sent to the clinical director of the Lifespan Cancer Institute by electronic mail (e-mail) explaining the project and support was obtained (Appendix C). An informational letter (Appendix D) and script (Appendix E) about the project was then sent by electronic mail (e-mail) to the nurses and nurse practitioners in the Lifespan Cancer Institute, who had at least one-year experience caring for cancer survivors. The questionnaire was emailed to participants and another email, approximately two weeks later, was sent to participants as a reminder of the project. Nurses and nurse practitioners had complete full disclosure with veracity about the project to allow them to make an informed decision to participate. Participation was voluntary and informed consent obtained. No risks were anticipated for participants and no identifying data was reported. The project's data was stored in a password-protected 
computer that only the student researcher had access to, and the questionnaire data results were stored in REDCap on an excel spreadsheet.

\section{Measurement}

The Caring for Patients Living With and Beyond Cancer questionnaire by Faithfull et al. (2016) was administered to participants (Appendix F). Permission to use the questionnaire was obtained and omission of questionnaire items that did not pertain to this specific project was granted from the primary author (Professor of Cancer Nursing Practice, Lead for Clinical Innovation Sara Faithfull PhD, MSc, BSc(Hons) RN) (Appendix G). The Caring for Patient Living With and Beyond Cancer questionnaire measures the self-reported assessment of competence on adult cancer survivorship management. It is designed to reflect four areas when caring for adult cancer survivors and includes clinical practice, symptom management, care coordination and proactive management (Faithfull et al., 2016). The questionnaire consists of four sections. The clinical practice section focuses on survivorship services provided and routine care planning with yes or no, frequency, and check all that apply questions. In the section on symptom management, there are questionnaire items that reflect a numeric rating scale 110 and Likert scale questions that range from strongly agree to strongly disagree in relation to managing symptoms commonly seen after cancer treatment. The third and fourth sections are care coordination and proactive care management and asks questions using a numeric rating scale of 1-10 on how easy role tasks are performed with cancer survivors (Faithfull et al., 2016). In addition, years of experience and future training needs are included in the questionnaire. The parts of the questionnaire that were not used for this project are: section one, question one and six, professional healthcare practice and 
how often do cancer patients seek help; section three, question ten, measurements or assessment tools; and section four specific to preference of training and resources for follow-up.

Faithfull et al. (2016) reported the psychometric properties of the questionnaire are being evaluated. The questionnaire was developed through a literature search of role requirements and piloted over two months. For this questionnaire, there was expert panel development to create content validity and expert practitioner feedback from oncology, community, and allied health professionals, patients, educators and service managers who reviewed the questionnaire for construct validity (Faithfull et al., 2016).

\section{Data Analysis/Outcomes}

Descriptive statistics were utilized to describe the participant sample including years of experience. Questionnaire responses were calculated to obtain statistical means and recorded in percentages. An additional desired outcome is to identify any educational needs participants may have. The overall long-term goal of this project is to possibly improve health care quality and therefore quality of life for cancer survivors by assessing self-perception of competence in survivorship care.

Next, the results will be presented. 


\section{Results}

\section{Sample}

Demographic data are depicted in table 1. A total of 29 female participants, twenty-five registered nurses (RNs) and four nurse practitioners (NPs), completed the questionnaire survey. Years of experience caring for cancer survivors ranged from 1 to more than 10 years with the majority of RNs having more than 10 years experience (17). Two NPs reported 1-5 years, one NP had 6-10 years, and one NP had more than 10 years of experience.

Table 1

Demographic Information

\begin{tabular}{|c|c|c|c|c|}
\hline Characteristics & $\begin{array}{l}\text { Number of } \\
\text { Participants }\end{array}$ & Percentage & \multicolumn{2}{|c|}{$\begin{array}{l}\text { Years of Experience } \\
\text { Caring for Cancer } \\
\text { Survivors }\end{array}$} \\
\hline Nurses & $\mathrm{N}=25$ & $86.2 \%$ & $\begin{array}{l}1-5 \\
6-10 \\
>10\end{array}$ & $\begin{array}{l}3 \text { Nurses } \\
5 \text { Nurses } \\
17 \text { Nuses }\end{array}$ \\
\hline Nurse Practitioners & $\mathrm{N}=4$ & $13.8 \%$ & $\begin{array}{l}1-5 \\
6-10 \\
>10\end{array}$ & $\begin{array}{l}2 \mathrm{NP} \\
1 \mathrm{NP} \\
1 \mathrm{NP}\end{array}$ \\
\hline
\end{tabular}

Nurses with 1-5 years experience and all nurse practitioners who participated, selfreported more competence in assessing late adverse effects of cancer treatment in cancer survivor patients they care for, in comparison to nurses with over ten years of experience who responded with the lowest competence scores and reported not often looking for late 
side effects. However, nurses with 6-10 years of experience felt neutral regarding this topic.

The perception of skills and competence of symptom management with cancer survivors was measured with a 5-point Likert scale ranging from strongly agree, agree, neither agree or disagree, disagree and strongly disagree. The responses from nurses and nurse practitioners varied with differences in symptom management across all years of nursing experience and reported different areas of self-confidence with skills. More than $50 \%$ of RNs and one NP, with only 1-5 years of experience, felt more confident in managing anxiety and depression (80\%), skin problems (80\%), and cardiac effects $(75 \%)$, while all nurses and NP's with 1-5 years of experience agreed they are $100 \%$ confident in managing neuropathy symptoms. In addition, one NP with 1-5 years experience felt less confident in the areas of managing anxiety and depression (20\%), and cardiac effects (25\%); however, RN's and one NP who had six to ten years experience were more competent $100 \%$ of the time in taking care of patients experiencing fatigue, as well as over $80 \%$, were confident in managing anxiety and depression. Likewise, more than $80 \%$ of RN's and one NP, who had over ten years of experience, self-reported high levels of confidence in pain management $(88.9 \%)$. Overall nurses and nurse practitioners felt knowledgeable in areas of pain management, fatigue, nausea and vomiting, and neuropathy, while on the other hand reported less confidence; and fewer skills in the areas of mobility issues, memory problems, loss of libido, impotence, sexual dysfunction, and fertility (Appendix H table 2).

Nurses and nurse practitioners reported various self-perceptions on whether it was easy or difficult to perform specific role tasks in caring for cancer survivors involving 
care co-ordination, proactive care, and surveillance which was measured with a 10-point Likert scale of 1 to $10 ; 1=$ easy to $10=$ difficult. Self-reported results amongst the nurses and nurse practitioners showed confidence levels between 1 even up to a 10 revealing difficulty with certain task roles (Appendix H table 3).

Nurses and nurse practitioners expressed educational interests in wanting to learn more about certain aspects of cancer survivorship care. The greatest interest areas were: long term health effects of cancer treatment (86.2\%), endocrine effects of cancer therapies $(87.2 \%)$, prevention and management of cancer treatment-induced bone loss and joint pain $(82.1 \%)$ and the potential cardiac effects of chemotherapies and hormone therapy tests $(82.8 \%)$. In addition, tests and investigations that are required after cancer therapy for late-effects surveillance (79.3\%), medication management and adherence (78.6\%), managing psycho-social aspects of long term cancer survival (75.0\%), assessment of sexual dysfunction and fertility (79.3\%), and self-management techniques (72.4\%) (Appendix H table 4).

\section{Summary and Conclusions}


The advances in cancer research with new medical treatments such as immunotherapies and early detection of cancer are improving a cancer patient's prognosis and life expectancy. The rate of cancer survivors is steadily increasing year after year and the NCIs current estimation for cancer survivors in the United States is 15.5 million. Many cancer survivors experience residual side effects from cancer or its treatment with chemotherapy that may be disabling acutely or long-term causing physical and psychological effects which can negatively affect quality of life. Cancer survivors can experience adverse physical side effects such as chronic pain, chronic fatigue, peripheral neuropathy, and cognitive memory impairment. Furthermore, anxiety and stress may exist from fear of cancer recurrence, the uncertainty of the future, the financial burden of having cancer, and lack of social support. Adverse side effects can begin during treatment and persist long after the completion of treatment or may not appear until many years later.

Cancer survivors can receive care in many areas of the healthcare system such as in the acute hospital, primary and outpatient settings. Competence and knowledge of cancer survivorship care are essential for good quality outcomes. Nurses and nurse practitioners can improve the quality of life for cancer survivors who have a variety of care needs with knowledge and competence in cancer survivorship care. Nurses and nurse practitioners can promote healthy lifestyles, provide education, emotional support, preventative care and cancer surveillance. Cancer survivorship involves many complex aspects of care but do all nurses and nurse practitioners caring for cancer survivors feel they have the skills to meet the unique needs of this patient population (Palos \& Zandstra, 2013)? Therefore, 
the purpose of this project was to examine oncology nurses' and nurse practitioners' selfperception of competence in cancer survivorship care.

This project used an adapted online questionnaire survey tool to measure selfperception of competence in cancer survivorship care in the areas of clinical practice, symptom management, care coordination, and proactive management. The one-time online questionnaire survey was sent to a convenience sample of oncology nurses and nurse practitioners who care for cancer survivor patients in an ambulatory outpatient cancer center. The sample who completed the survey consisted of 29 participants in which twenty-five were nurses and four nurse practitioners. The survey also consisted of questions on descriptive demographics whether they were a nurse or nurse practitioner and years of experience caring for cancer survivors in which the range was 1.5 to greater than ten years.

Nurses and nurse practitioners self-perception of their role of care they provide to cancer survivors revealed nurses with 1-5 years experience and all nurse practitioners regardless of years of experience self-reported assessing for late adverse effects of cancer treatment in cancer survivor patients. Late effects were being monitored quite often compared to sixty percent of nurses with over ten years of experience responded with the lowest rating and reported not looking for late side effects. However, the nurses with 610 years experience felt neutral on this topic.

The majority $(80 \%)$ of nurses and nurse practitioners reported ease with caring for cancer survivors in the areas of symptom management with pain, fatigue, nausea and 
vomiting, anxiety, depression and neuropathy while feeling less competent in the areas of mobility issues, memory problems, loss of libido, impotence, sexual dysfunction and infertility.

Nurses and nurse practitioners revealed various confidence levels on whether it was easy or difficult to perform specific role tasks in caring for cancer survivors involving care co-ordination, proactive care, and surveillance which was measured with a 10-point Likert scale of 1 to $10 ; 1=$ easy to $10=$ difficult. Nurses and nurse practitioners reported self-perception of confidence ranging from one as they felt specific tasks were easy to a ten finding it difficult to perform.

This project has identified areas for ongoing continuing cancer survivorship education in caring for cancer survivors based upon the survey participants level of selfreported feelings of knowledge and educational interests. The results of this project are consistent with evidence found in the literature of other research studies supporting the need for continuing education related to deficits in knowledge in cancer survivorship care (Faithfull et at., 2016; Irwin et al., 2011; Klemp et al., 2011; Lester et al., 2014).

There are some limitations to this project. These limitations included a small convenience sample size, which contributed to a small participation response rate. Also, there was a lack of gender diversity among the participants. The convenience sample was comprised of only female nurses and nurse practitioners with no male nurses or nurse practitioners.

There is limited generalizability with the questionnaire survey response results as it was only utilized at one cancer center. The questionnaire addressed self-reported 
competence, were the identified strengths and weaknesses from nurses and nurse practitioners may not reflect actual competence.

Recommendations and Implications for Advanced Nursing Practice 
This project supports the need for continuing education and competency in cancer survivorship care, which is essential to ensure patient safety and quality of care for cancer survivors. Oncology nurses and nurse practitioners often work in specific specialized areas of oncology, which can be beneficial as they have expertise knowledge within that particular cancer patient population; however, working in a specialized area may result in less knowledge of care in other types of cancers. Nurses and nurse practitioners can play a significant role in improving the quality of life of cancer survivors by having the knowledge and being competent in cancer survivorship care. Nurses and nurse practitioners are the leaders in cancer survivorship care and should increase their knowledge in all aspects of cancer survivorship by participating in continuing education and training that will enhance competence and skills. Nurses and nurse practitioners can increase their knowledge on cancer survivorship care from online learning, books on cancer survivorship, conferences, and through many organizations to name a few such as the Oncology Nursing Society and the National Coalition for Cancer Survivorship. Volker et al., (2011) research supports access for all nurses and nurse practitioners in all healthcare practice settings to evidence-based educational opportunities and resources to promote ongoing competency to meet self-identified needs, priorities, and self-reported gaps in existing cancer survivorship knowledge and practice. Institutional support within the workplace setting should address and provide educational assistance for nurses and nurse practitioners in cancer survivorship, which is imperative for the upmost quality of care that cancer survivor patients deserve. Grant, Economou, Ferrell, and Uman (2012) mention that survivorship care requires an interdisciplinary care team approach involving nurses, nurse practitioners, and staff from many disciplines working together to meet the 
needs of the cancer survivor. Nurses and Nurse Practitioners should take advantage of an interdisciplinary approach to cancer survivorship care by using more referrals and services with other healthcare professionals such as palliative care.

More research is needed on effective, innovative teaching methods for cancer survivorship education and the preferred learning styles amongst nurses and nurse practitioners (Klemp et al., 2011). Therefore, as the population of cancer survivors increases, it is imperative for nurses and nurse practitioners, across all diverse settings, to be knowledgeable in providing competent care to cancer survivors.

\section{References}

Altice, C. K., Banegas, M. P., Tucker-Seeley, R. D., \& Yabroff, K. R. (2017). Financial 
hardships experienced by cancer survivors: A systematic review. Journal

National Cancer Institute, 109(2), 1-17. https://doi.org/10.1093/jnci/djw205

American Cancer Society. (2015). What is cancer? Retrieved June 28,

2018, from https://www.cancer.org/cancer/cancer-basics/what-is-cancer.html

American Cancer Society. (2016). How is chemotherapy used to treat cancer. Retrieved June 28, 2018, from https:// www. cancer.org/.../chemotherapy/how-ischemotherapy-used-to-treat-cancer.html

American Society of Clinical Oncology. (2016a). What is Survivorship? Retrieved June 15, 2018, from https://www.cancer.net/survivorship

American Society of Clinical Oncology. (2016b). Models of long-term follow-up care. Retrieved July 18, 2018, from https://www.asco.org/practice.../cancercare...survivorship/survivorship/survivorship-3

Argyriou, A. A., Assimakopoulos, K., Iconomou, G., Giannakopoulou, F., \& Kalofonos, H. P. (2011). Either called "chemobrain" or chemofog," the long-term chemotherapy-induced cognitive decline in cancer survivors is real. Journal of Pain and Symptom Management, 4(1), 126-139.

https://doi.org/10.1016/j.jpainsymman.2010.04.021

Bernard, D. S., Farr, S. L., \& Fang, Z. (2011). National estimates of out-of-pocket health care expenditure burdens among nonelderly adults with cancer: 2001 to 2008 . 
Journal Of Clinical Oncology, 29(20), 2821-2826.

https://doi.org/10.1200/JCO.2010.33.0522

Christensen, M. (2011). Advancing nursing practice: Redefining the theoretical and practical integration of knowledge. Journal of Clinical Nursing, 20(5-6), 873-881. https://doi.org/10.1111/j.1365-2702.2011.03837.x

Corcoran, S., Dunne, M., \& McCabe, M. S. (2015). The role of advanced practice nurses in cancer survivorship care. Seminars in Oncology Nursing, 3(4), 338-347. https://doi.org/10.1016/j.soncn.2015.08.009

De Raaf, P. J., De Klerk, C., Timman, R., Hinz, A., \& Van der Rijt, C. (2012). Differences in fatigue experiences among patients with advanced cancer, cancer survivors, and the general population. Journal of Pain and Symptom Management, 44(6), 823-830.https://doi.org/10.1016/j.jpainsymman.2011.

Faithfull, S., Samuel, C., Lemanska, A., Warnock, C., \& Greenfield, D. (2016). Selfreported competence in long term care provision for adult cancer survivors: A cross sectional survey of nursing and allied health care professionals. International Journal of Nursing Studies, 53, 85-94. https://doi.org/10.1016/j.ijnurstu.2015.09.001

Fenn, K. M., Evans, S. B., McCorkle, R., DiGiovanna, M. P., Pusztai, L., Sanft, T., ...Chagpar, A. B. (2014). Impact of financial burden of cancer on survivors' 
quality of life. Journal Of Oncology Practice, 10(5), 332-338.

https://doi.org/10.1200/JOP.2013.001322

Finocchio, L. F., Dower, C. M., Blick, N. T., \& Gragnola, C. M., and the Task Force on Health Care Workforce Regulation (1998). Strengthening consumer protection: Priorities for health care workforce regulation. San Francisco, California: Pew Health Professions Commission. Retrieved June 26, 2018, from https:/healthforce.ucsf.edu/sites/healthforce.ucsf.edu/files/publication-pdf/ 4.1\%20\%28Report\%29\%201998-12_Strengthening_Consumer_Protection_ Priorities_for_Health_Care_Workforce_Regulation.pdf

Forsythe L. P., Alfano, C. M., George S. M., McTiernan A., Baumgartner, K. B., Bernstein, L., Ballard-Barbash, R. (2013). Pain in long-term breast cancer survivors: The role of body mass index, physical activity, and sedentary behavior. Breast Cancer Research and Treatment, 137(2), 617-630. https://doi.org/10.1007/s10549-012-2335-7

Geller, B. M., Vacek, P. M., Flynn, B. S., Lord, K., \& Cranmer, D. (2014). What are cancer survivors' needs and how well are they being met? The Journal of Family Practice, 63(10), E7-E16. Retrieved from jfponline.com

Glare, P. A., Davies, P. S., Finlay, E., Gulati, A., Lemanne, D., Moryl, N., ... Syrjala, K. L. (2014). Pain in cancer survivors. Journal Of Clinical Oncology, 32(16), 
1739-1747. https://doi.org/10.1200/JCO.2013.52.4629

Grant, M., Economou, D., Ferrell, B., \& Uman, G. (2012). Educating health care professionals to provide institutional changes in cancer survivorship care. Journal of Cancer Education, 27(2), 226-232. https://doi.org/1007/s 13187-012-0314-7

Goedendorp, M. M., Gielissen, M.F., Verhagen, C.A., \& Bleijenberg, G. (2013). Development of fatigue in cancer survivors: A prospective follow-up study from diagnosis into the year after treatment. Journal of Pain and Symptom Management, 45(2), 213-222. https://doi.org/10.1016/j.jpainsymman.2012.02.009

Green, C. R., Hart-Johnson, T., \& Loeffler, D. R. (2011). Cancer-related chronic pain: Examining quality of life in diverse cancer survivors. Cancer, 117(9), 1994-2003. https://doi.org/10.1002/cncr.25761

Hewitt, M., Greenfield, S., \& Stovall, E. (2006). From cancer patient to cancer survivor: Lost in Transition. Washington, DC: The National Academies Press. Retrieved July 3, 2018, from https://www.nap.edu/catalog/11468

Irvine, D., Sidani, S., \& McGillis Hall, L. (1998). Linking outcomes to nurses' roles in health care. Nursing Economics\$, 16(2), 58-64, 87.

Irwin, M., Klemp, J. R., Glennon, C., \& Frazier, L. M. (2011). Oncology nurses’ 
perspectives on the state of cancer survivorship: Current practice and barriers to implementation. Oncology Nursing Forum, 38(1), E11-E19.

Khan, N. F., Rose, P. W., \& Evans, J. (2011). Defining cancer survivorship:

A more transparent approach is needed. Journal of Cancer Survivorship, 6(1), 33-36. https://doi.org/10.1007/s11764-011-0194-6

Klemp, J. R., Frazier, L. M., Glennon, C., \& Trunecek, J. (2011). Improving cancer survivorship care: Oncology nurses' educational needs and preferred methods of learning. Journal of Cancer Education, 26(2), 234-242. https://doi.org/10.1007/s13187-011-0193-3

Lebel, S., Tomei, C., Feldstain, A., Beattie, S., \& McCallum, M. (2013).

Does fear of cancer recurrence predict cancer survivors' health care use? Supportive Care in Cancer, 21(3), 901-906. https://doi.org/10.1007/s00520-012-1685-3

Lenihan, D. J., \& Cardinale, D. M. (2012). Late cardiac effects of cancer treatment. Journal Of Clinical Oncology, 30(30), 3657-3664. https://doi.org/10.1200/JCO.2012.45.2938

Lester, J. L., Wessels, A. L., \& Jung, Y. (2014). Oncology nurses’ knowledge of 
survivorship care planning: The need for education. Oncology Nursing Forum, 41(2), 35-43. https://doi.org/10.1188/14.ONF.E35-43

Mayer, D. K., Nasso, S. F., \& Earp, J. A. (2017). Defining cancer survivors, their needs and perspectives on survivorship health care in the USA. The Lancet Oncology, 18(1), e11-e18. https://doi.org/10.1016/S1470-2045(16)30573-3

Miaskowski, C., Mastick, J., Paul, S. M., Topp, K., Smoot, B., Abrams, G., ...Levine, J. D. (2017). Chemotherapy-Induced neuropathy in cancer survivors. Journal of Pain and Symptom Management, 54(2), 204-218. https://doi.org/10.1016/j.jpainsymman.2016.12.342

Morgan, M. A. (2009). Cancer survivorship: History, quality-of-life issues, and the evolving multidisciplinary approach to implementation of cancer survivorship care plans. Oncology Nursing Forum, 36(4), 429-436. https://doi.org/10.1188/09.ONF.429-436

Mullen, F. (1985). Seasons of survival: Reflections of a physician with cancer. The New England Journal of Medicine, 313(4), 270-273. https://doi.org/10.1056/NEJM198507253130421

National Cancer Institute (2015a). Chemotherapy to treat cancer. Retrieved June 28, 2018, from https://www.cancer.gov/about-cancer/treatment/types/chemotherapy.

National Cancer Institute (2015b). What is Cancer. Retrieved August 2, 2018, from https://www.cancer.gov/about-cancer/understanding/what-is-cancer 
National Cancer Institute (2015c). NCI dictionary of cancer terms. Retrieved July 4, 2018, from https://www.cancer.gov/publications/dictionaries/ cancer-terms/def/survivor

National Cancer Institute (2016). Statistics-Office of Cancer Survivorship Retrieved May 23, 2018, from https://cancercontrol.cancer.gov/ocs/statistics/statistics.html.

National Cancer Institute (2018). Cancer Statistics. Retrieved June 16, 2018, from https://www.cancer.gov/about-cancer/understanding statistics

National Cancer Survivorship Resource Center (2012). Quality of life: Programs and navigation overview. Retrieved July 11, 2018, from http://www.cancer.org/acs/groups/content/@editorial/Document/acspc031410.pdf

National Coalition for Cancer Survivorship (1995). Defining cancer survivor. Retrieved July 4, 2018, from https://www.canceradvocacy.org/about-us/our-history/defining cancer survivor

National Coalition for Cancer Survivorship (2014). Defining cancer survivorship. Retrieved July 4, 2018, from https://www.cancer advocacy.org/news/definingcancer-survivorship 
Palos, G. R., \& Zandstra, F. (2013). Call for action: Caring for the United States' aging cancer survivors. Clinical Journal of Oncology Nursing, 17(1), 88-90. https://doi.org/10.1188/13.CJON.88-90

Prasad, V., De Jesus, K., \& Mailankody, S. (2017). The high price of anticancer drugs: Origins, implications, barriers, solutions. Nature Reviews Clinical Oncology, 14(6), 381-390. https://doi.org/10.1038/nrclinonc.2017.31

Sakar, S., Sautier, L., Schilling, ZG., Bokemeyer, C., Koch, U., \& Mehnert, A. (2015). Anxiety and fear of cancer recurrence and its association with supportive care needs and health-care service utilization in cancer patients. Journal Cancer Survivorship, 9(4), 567-575. https://doi.org/10.1007/s11764-015-0434-2

Sinha, D. K. (2018). Difference between competence and competency. Retrieved July 4, 2018, from www.yourarticlelibrary.com/entrepreneurship/difference-betweencompetence-and competency-explained-with-diagram/40696

Volker, D. L., Watson, J., Becker, H., \& Scott, T. (2011). Assessing cancer-related learning needs of Texas nurses. Cancer Nursing, 34(5), E20-E27. https://doi.org/10.10.1097/NCC.0b013e31820641be

Watts, T. (2011). Caring for cancer survivors. Practice Nurse, 41(12), 40-45.

Weaver, L. C., Jessup, A., \& Mayer, D. K. (2013). Cancer survivorship care: Implications for primary care advanced practice nurses. The Nurse Practitioner, 38(11), 1-11. https://doi.org/10.1097/01.NPR.0000435784.40143.62 
Wronski, S. L. (2015). Defining cancer survivor and cancer survivorship: The who, what, and when. Psicooncologia, 12(1), 7-18. https://doi.org/10.5209/rev_PSIC.2015.v12.n1.48900

Zebrack, B. J. (2000). Cancer survivor identity and quality of life.

Cancer Practice, 8(5), 238-242. Retrieved from www. American Cancer Society.org. https://doi.org/10.1046/j.1523-5394.2000.85004.X 


\section{Appendix A}

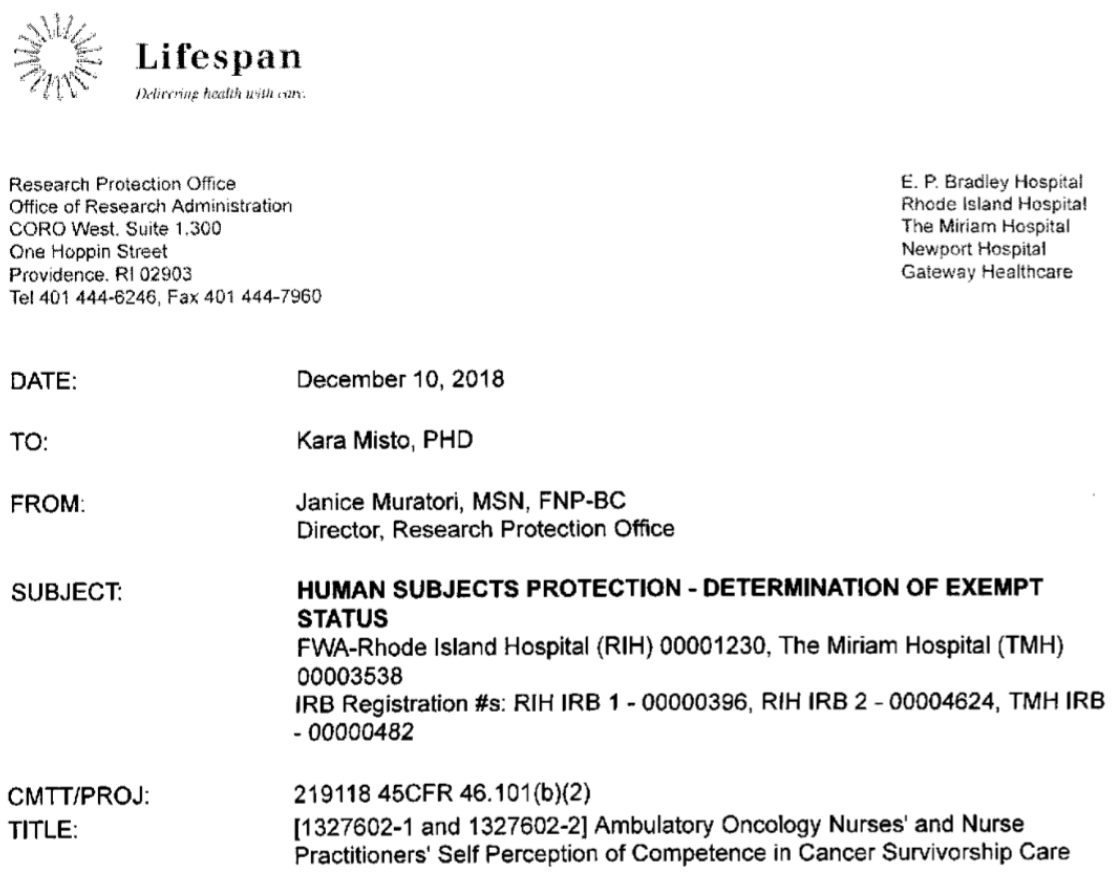

Your research application submitted on November 13, 2018 was reviewed and determined to be exempt from the Federal Regulation 45 CFR 46 as meeting the criteria in 45 CFR 46.101(b)(2). Projects determined to meet the exempt criteria by the IRB are exempt from continuing review by the IRB, as long as the project maintains the properties that make it exempt.

This means:

1. You do not need to renew your application annually.

2. You do not need to submit a revision application to make changes in your project unless the modification will cause the research to change from Exempt to Expedited or Full Review Status as ffor 45 CFR 46.

Revisions that may change the status of this determination must be submitted to the IRB for review.

This institution is in compliance with the ICH GCP as they correspond to the FDADHHS regulations. This review is applicable for TMH.

Please contact the Research Protection Office if you have any questions. 


\section{Appendix B}

From: NoReplyRIC_Elements@topazti.net <NoReplyRIC_Elements@topazti.net

Sent: Tuesday, January 15, 2019 11:02 AM

To: Institutional Review Board - Rhode Island College; Dame, Linda M.

Subject: IRB: \#1819-1767 (Dame, Linda) approved

Greetings,

The proposal for the project referenced below has been DETERMINED TO BE EXEMPT by the Institutional Review Board (IRB).

Project title: Ambulatory Oncology Nurses' and Nurse Practitioners' Self-Perception of Competence in Cancer Survivorship Care

Approval \#: 1819-1767

Type of review: Exempt

Proposal type: Original

Principle Investigator: Dame, Linda

Fees received: 1. No fees -- RIC supervised or sponsored

Funding status:

Approval date: $1 / 15 / 2019$

You do not need to submit any renewals for this project.

An exemption is not the same as approval. This protocol has been reviewed to ensure it meets the criteria for an exemption, but it has not been reviewed for approval. Investigators are encouraged to adhere to the same ethical standards of research for non-exempt research. References to the IRB status cannot say that it was approved, but must say that the study was determined to be Exempt from Continuing Review. Any changes to the scope or methods of your research may change its status and must be reviewed by the IRB before implementation.

Click here to access the protocol: https://ric.topazti.net/RIC/SL/Default.aspx?

linkParms $=N P g k Q N f Z c n V x R Y y 2 K O C G u Q \% 3 d \% 3 d$

Do not reply to this "RIC_Elements" email address because it will not be received by the IRB. Send all correspondence to IRB@ric.edu.

\section{Best Regards,}

Emily Cook, Ph.D.

Associate Professor

Chair, IRB

Rhode Island College

IRB@ric.edu 


\section{Appendix C}

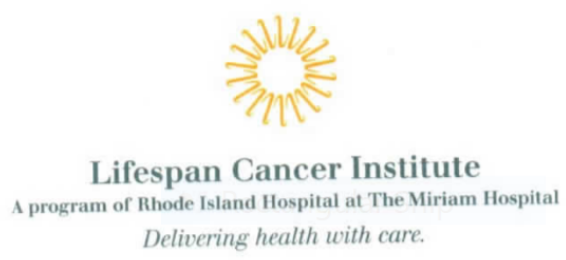

Hematology/Oncology

164 Summit Avenue

Providence, RI 02906

October 1,2018

Tel $844222-2881$

Fax 401 793-2859

To Whom It May Concern,

I wish to fully endorse the project by Tracy Carraggi to be completed at the Lifespan

Cancer Institute on "Ambulatory Oncology Nurses and Nurse Practitioners Self-Perception

of Competence in Cancer Survivorship Care". I am happy to assist in any way we can for the completion

toward her degree.

If there are any questions or concerns related to this project, please contact me as I can be available for

help.

Best of luck,

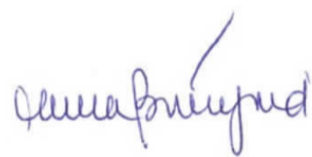

Laura Butterfield

Director of the Lifespan Cancer Institute- The Miriam Campus

164 Summit Ave

Providence, RI 02906

Office 401-793-3305

Cell \# 401-588-0761

Ibutterfield@lifespan.org 


\section{Appendix D}

\begin{tabular}{|ll|}
\hline IRB Approval: & $12 / 7 / 2018$ \\
\hline IRB Accepted: & $12 / 7 / 2018$ \\
\hline
\end{tabular}

Informational Letter

My name is Tracy L Carraggi, and I am a graduate student at Rhode Island College. I will be conducting a Master's project along with principal investigator, Kara Misto called Ambulatory Oncology Nurses' and Nurse Practitioners' Self Perception of Competence in Cancer Survivorship Care.

I am writing to invite you to participate. The purpose of this project is to measure nurses and nurse practitioners self-perception of competence in cancer survivorship care. The goal of this project is to hopefully improve health care quality and therefore quality of life for cancer survivors by assessing self-perception of competence in survivorship care and to identify any educational needs for participants.

You will be asked to complete a one-time on-line questionnaire. Your completing this questionnaire will take approximately 10 minutes of your time. There are four sections in the questionnaire with yes and no, check all that apply, strongly agree or strongly disagree, and numeric rating scale questions. This questionnaire is the only thing that will be asked of you. There are no questions that should cause you any discomfort. The completion of this questionnaire may not benefit you personally. Taking part in this questionnaire is completely voluntary. If you choose to participate, you can access the questionnaire by clicking on the link at the end of this letter. If you do not want to complete the questionnaire, you are free to choose not to fill out the questionnaire.

The data from this project will be kept anonymous. None of the information you provide will have your name or any number on it that will identify you personally. If you have any questions about the questionnaire or the project itself, please feel free to contact me at TBARROWS_4519@email.ric.edu or the principal investigator of this project Kara Misto, Ph.D. at kmisto@lifespan.org. If you have any questions about your rights, please feel free to call the office of Research Administration manager, Janice Muratori, at 444-6897.

Thank you very much for your time,

Tracy L. Carraggi, BSN, RN, OCN

Acute Care NP Student

Rhode Island College

TBARROWS_4519@email.ric.edu 


\section{Appendix E}

\section{Informational Script}

\begin{tabular}{|lr|}
\hline IRB Approval: & $12 / 7 / 2018$ \\
\hline IRB Accepted: & $12 / 7 / 2018$ \\
\hline
\end{tabular}

Hello, my name is Tracy Carraggi. I am a graduate student at Rhode Island College in the Adult/Gerontology Acute Care Nurse Practitioner Program. I am conducting a project on the ambulatory oncology unit, at the Fain Clinic, titled "Ambulatory Oncology Nurses' and Nurse Practitioners' Self Perception of Competence in Cancer Survivorship Care". I am inviting you to participate since you care for cancer survivors. The purpose of this project is to assess nurses and nurse practitioners self-perception of competence in cancer survivorship care. The overall goal of this project is to hopefully improve health care quality and therefore the quality of life for cancer survivors by assessing self-perception of competence in survivorship care and to identify any educational needs of nurses and nurse practitioners. The principal investigator of this project is Kara Misto, Ph.D. and I will be the student researcher on the project. Participation is voluntary and you can withdraw at any time. Participation will involve completing a one-time electronic questionnaire and should take approximately 10 minutes to complete. The information you provide will be anonymous. By participating in this project, there are no risks and no direct benefits to you.

Thank you very much for your time,

Tracy L. Carraggi, BSN, RN, OCN 
Appendix F

WE ARE MACMILLAN, CANCER SUPPORT

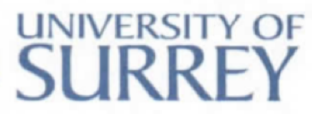

\section{Caring for patients living with and beyond cancer competency tool}

SECTION ONE: This section asks about your clinical practice, that you provide for patients post cancer treatment. Please complete all sections following the instructions set out against each question.

Q1: Which professional health care practice group are you working within?

Oncology Nurse

Community Nurse

Allied Health Professional

Q2: Which of the following Clinical Practices do YOU provide to cancer patients following cancer treatment?

Please tick all that apply

Review and assessment after 12 months

Checks for cancer recurrence

Telephone follow up

Screening advice for cancer patients

Triage and referral to the physician

Reassure patients about their health and emotions

Long term medications management for cancer therapies

Symptom and side effect management of cancer treatment

Nutritional, exercise and lifestyle advice

Opportunity to talk to staff who understand a cancer diagnosis

Other please specify:

Q3: What proportion of your patients are follow-up cancer patients?
Very few
Few
Don't know
Many
Very many 
$\begin{array}{lllll}\text { Q4: } & \begin{array}{l}\text { Do you specifically look for late adverse } \\ \text { effects of cancer treatments? }\end{array} & \square & \text { Yes } \\ \text { Q5: } & \begin{array}{l}\text { Do you routinely provide a plan of care to } \\ \text { cancer patients after treatment? }\end{array} & \begin{array}{l}\square \\ \text { Yes }\end{array} & & \text { No }\end{array}$

Q6: Within your practice how often do your cancer patients seek help for the symptoms listed below following their cancer treatment?

Stress

Sexual dysfunction (women)

Bone pain

Lymph oedema

Skin issues

Fatigue

Urinary function

Breathlessness

Weight gain

Limb mobility issues (e.g. shoulder)

Sleep problems

Loss of libido

Impotence (Erectile dysfunction in men) ${ }^{2}$

General pain management

Bowel problems

Nerve pain

Incontinence/ leakage

Fertility issues

Digestive problems

Anxiety/Depression

Fear (of recurrence)

Self-confidence issues

Cognitive (memory concerns)

Hot flushes

Dietary advice

Exercise advice

Lifestyle change advice

Menopausal concerns

Financial and insurance issues

General health problems

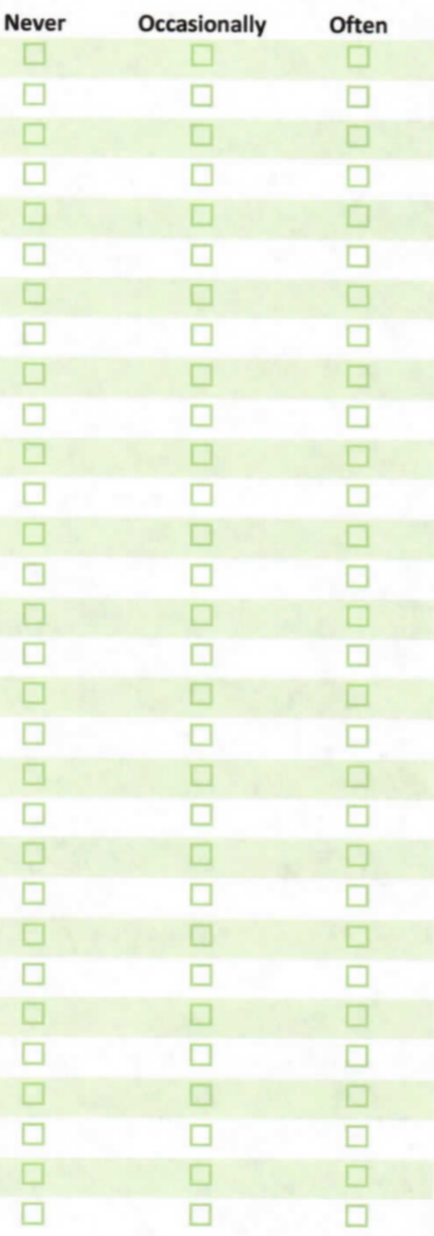


SECTION TWO: System Management: We would like to know whether you feel you have the skills to manage symptoms patients present with as a consequence of cancer treatment. Please indicate how much you agree or disagree by selecting the statement that best describes how you feel.

Q7: I possess the skills to manage these
$\begin{aligned} & \text { Strongly } \\ & \text { Agree }\end{aligned}$ $\begin{aligned} & \text { Agree } \\ & \text { Please identify all that opply from the list below: }\end{aligned} \begin{aligned} & \begin{array}{l}\text { Neither } \\ \text { agree or } \\ \text { disagree }\end{array} \\ & \text { General pain } \\ & \text { Bone and joint pain }\end{aligned}$


Q8: We would also like to know how easy or difficult it is for you to manage those individuals who have received cancer treatment in the past. Please mark how easy or difficult each task is for you on the scale of $1-10 .(1=$ easy and $10=$ difficult $)$

\section{CAN:}

Recognise the symptoms associated with late effects of cancer treatment.

Recognise the psychological and social problems

associated with long term cancer survivorship

Inform and discuss potential long-term health

effects with patients.

Provide psychological support to patients

following cancer treatment.

Provide symptom management for mild to moderate side effects from cancer treatment.

Provide complex symptom management for

severe symptoms as a result of cancer and its treatment.

SECTION THREE: Care Co-ordination: This section asks about care co-ordination, surveillance plans, across the care pathway

Q9: We would also like to know how easy or difficult it is for you to manage those individual who have received cancer treatment in the past. Please mark how easy or difficult each task is fo you on the scale of $1-10 .(1=$ easy and $10=$ difficult $)$

I CAN:

$\begin{array}{llllllllll}1 & 2 & 3 & 4 & 5 & 6 & 7 & 8 & 9 & 10\end{array}$

Review and assess patients independently and then consult with a clinician.

Independently review and assess patients

following cancer treatment.

Review medications and to advise patients on

their potential effects.

Refer patients to the multi-disciplinary team.

Effectively teach self-management and self-

monitoring for cancer patients post therapy.

Create an individualised long-term plan of care

for recovery and wellbeing.

Recognise the potential late-effects of my client

group.

$\begin{array}{llllllllll}1 & 2 & 3 & 4 & 5 & 6 & 7 & 8 & 9 & 10\end{array}$

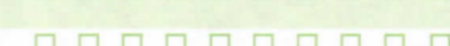

on

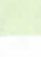

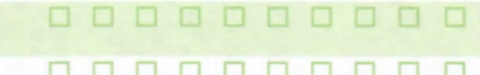

(1)

ent
. 
Q 10: Do you use any measurements or assessment tools for

entifying cancer patient's needs following cancer

treatment? Please select all methods thot opply to your

practice

Physical examination (e.g. range of movement)

Structured interviews

Late-effects tools, e.g. LENT SOMA scale

Symptom assessment

Distress/concerns thermometer

Hospital Anxiety and Depression Scale (HADS)

Sheffield Profile for Assessment and Referral for Care

(SPARC)

Holistic Needs Assessment (HNA)

Other, please specify:

\begin{tabular}{|c|}
\hline \\
\end{tabular}


SECTION FOUR: In this section we would like to ask about areas you would like to know more about and resources you may require to provide a quality follow up service for patients following cancer treatment.

Which areas of cancer care would you like to know more about to help you manage your patients' care? Please tick all that apply

Knowledge of long term health effects of cancer treatment

Endocrine effects of cancer therapies

Tests and investigations required after cancer therapy (i.e. late-effects surveillance)

Prevention and management of cancer treatment induced bone loss and joint pain

Potential cardiac effects of chemotherapies and hormone therapies

Assessing and managing pelvic problems post cancer surgery and radiotherapy Cancer surgeries and subsequent effects on physiological and functional processes

Co-ordinating long term follow up for patients no longer attending hospital follow up clinics

Rehabilitation

Lifestyle activity

Exercise

Medications management and adherence

Managing psycho-social aspects of long term cancer survival

Assessment of sexual dysfunction and fertility

Self-management techniques

Assessment and screening for cancer patients longer term

Telephone follow up techniques

Long term consequences of cancer treatments in older age

Other, please specify:

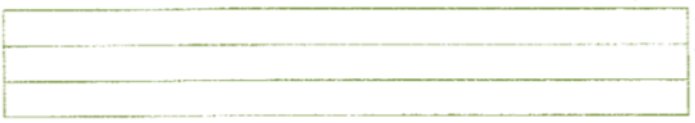


If you were given the choice of recelving additional training for managing the long-term effects of cancer, how would you prefer to recelve your training?

Tick ail that apply

Short conferences or workshops (up to $/ /$ day)

Longer conferences or workshops (up to 1 week)

Distance learning

Web based e-learning

Day to day patient contact

Clinical practice with mentor

Practical and theory combined courses of academic

quality

Other, please specify:

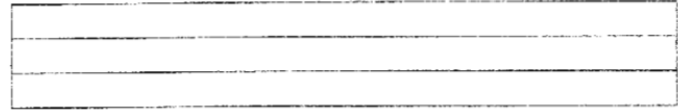

Are there other resources that would help you in providing a follow-up service for patients following cancer treatment? Pleose specify.

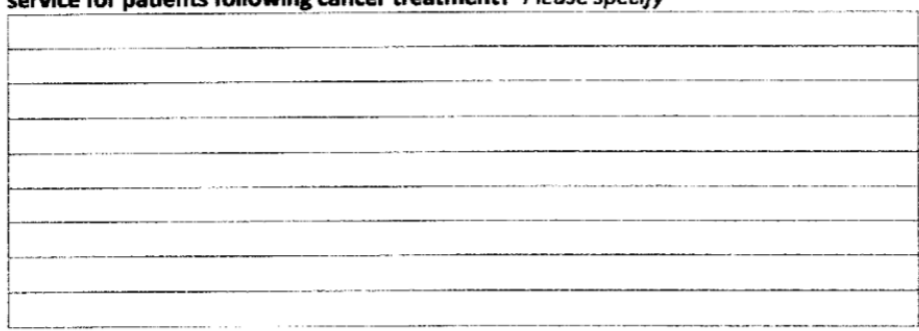

Thank you for taking the time and effort to complete this questionnaire. Your responses will help us to identify the training needs of cancer nurses who are currently working with people who have previously had cancer. 


\title{
Appendix G
}

\section{Re: Survey Tool "Caring for patients living with and beyond cancer competence tool"}

\author{
s.faithfull@surrey.ac.uk \\ Thu 5/24/2018 3:36 AM \\ To.Carraggi, Tracy L. <tbarrows_4519@email.ric.edu>;
}

Dear Tracey very happy for you to use the questionnaire in your masters study. if you can then keep me informed as to the outcomes from your work, this will be very interesting. We also have a UK competency document that is linked to this to guide staff and managers that may prove helpful. Best wishes Sara

https://www.macmillan.org.uk/images/competence-framework-for-nurses tcm9-297835.pdf

On 24 May 2018, at 06:22, Carraggi, Tracy L. <tbarrows 4519@email.ric.edu> wrote:

Dear Dr. Faithfull,

Hello, my name is Tracy Carraggi RN BSN OCN, a graduate masters student at Rhode Island College Providence, R. I. in the United States. I am starting a research study on "Exploring Oncology Staff perceptions on caring for cancer survivors in a Comprehensive Cancer Center". I am respectively requesting permission to use the survey tool that was used in your study, "Self-reported competence in long term care provision for adult cancer survivors: A cross sectional survey of nursing and allied health care professionals," International Journal of Nursing Studies, 53 (2016) 85-94. I may need to make modifications of deleting some items to the survey that do not pertain to my research study. The Master's Research Project will be made public through Digital Commons at Rhode Island College. Thank you for any assistance, I look forward to your email response. Please let me know if any further information is needed. To confirm my email address is TBARROWS4519@email.ric.edu 


\section{Appendix H}

\section{$\underline{\text { Clinical Practice }}$}

\section{Table 1}

\section{What Of The Following Clinical Practices Do You Provide To Cancer Patients}

\section{Following Cancer Treatment, Check all that apply}

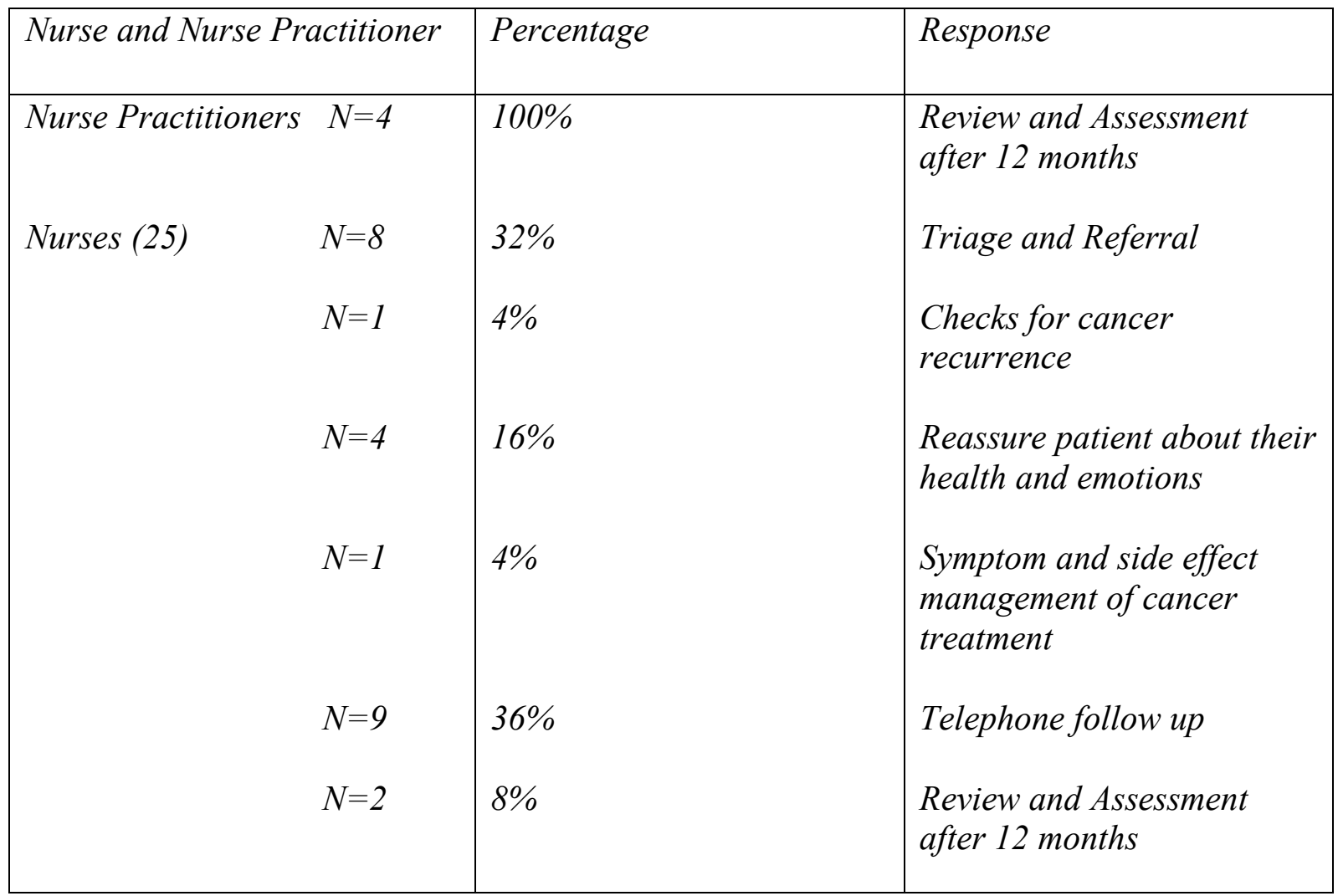

Do You Specifically Look for Late Effects Of Cancer Treatment?

\begin{tabular}{|l|l|l|l|}
\hline & \multicolumn{1}{|c|}{$1-5$} & \multicolumn{1}{|c|}{$6-10$} & \multicolumn{1}{c|}{$\mathrm{N}=5$} \\
Nurse & N=5 & $40 \%$ yes & $27.8 \%$ yes \\
& $40 \%$ yes & $40 \%$ no & $66.7 \%$ no \\
Nurse Practitioners & $40 \%$ yes & $20 \%$ yes & $5.56 \%$ yes \\
& & & \\
\hline
\end{tabular}


Table 2

Perceived confidence and skills in symptom management

Whether you feel you have the skills to manage symptoms patients present with as a consequence of cancer or its treatment $\mathbf{N}=$ Nurse $\mathbf{N P}=$ Nurse Practitioner

\begin{tabular}{|c|c|c|c|c|c|}
\hline $\begin{array}{l}\text { Symptoms/Years } \\
\text { of experience }\end{array}$ & $\begin{array}{l}\text { Strongly } \\
\text { Agree }\end{array}$ & Agree & $\begin{array}{l}\text { Neither } \\
\text { agree or } \\
\text { disagree }\end{array}$ & Disagree & $\begin{array}{l}\text { Strongly } \\
\text { Disagree }\end{array}$ \\
\hline \multicolumn{6}{|l|}{ Pain } \\
\hline $1-5$ & & $\begin{array}{l}80 \% \\
3 \mathrm{~N}+1 \mathrm{NP}\end{array}$ & & & $\begin{array}{l}20 \% \\
1 \mathrm{NP}\end{array}$ \\
\hline $6-10$ & & $\begin{array}{l}50 \% \\
2 \mathrm{~N}+1 \mathrm{NP}\end{array}$ & $\begin{array}{l}50 \% \\
3 \mathrm{~N}\end{array}$ & & \\
\hline$>10$ & $\begin{array}{l}27.8 \% \\
4 \mathrm{~N}+1 \mathrm{NP}\end{array}$ & $\begin{array}{l}61.1 \% \\
11 \mathrm{~N}\end{array}$ & $\begin{array}{l}11.1 \% \\
2 \mathrm{~N}\end{array}$ & & \\
\hline \multicolumn{6}{|l|}{$\begin{array}{l}\text { Bone and } \\
\text { joint pain }\end{array}$} \\
\hline $1-5$ & & $\begin{array}{l}80 \% \\
3 \mathrm{~N}+1 \mathrm{NP}\end{array}$ & & & $\begin{array}{l}20 \% \\
1 \mathrm{NP}\end{array}$ \\
\hline $6-10$ & & $\begin{array}{l}50 \% \\
2 \mathrm{~N}+1 \mathrm{NP}\end{array}$ & $\begin{array}{l}33.3 \% \\
2 \mathrm{~N}\end{array}$ & $\begin{array}{l}16.7 \% \\
1 \mathrm{~N}\end{array}$ & \\
\hline$>10$ & $\begin{array}{l}22 \% \\
3 \mathrm{~N}+1 \mathrm{NP}\end{array}$ & $\begin{array}{l}56 \% \\
10 \mathrm{~N}\end{array}$ & $\begin{array}{l}22 \% \\
4 \mathrm{~N}\end{array}$ & & \\
\hline \multicolumn{6}{|l|}{ Lymphedema } \\
\hline $1-5$ & & $\begin{array}{l}60 \% \\
2 \mathrm{~N}+1 \mathrm{NP}\end{array}$ & & $\begin{array}{l}20 \% \\
1 \mathrm{~N}\end{array}$ & $\begin{array}{l}20 \% \\
1 \mathrm{NP}\end{array}$ \\
\hline $6-10$ & & $\begin{array}{l}50 \% \\
2 \mathrm{~N}+1 \mathrm{NP}\end{array}$ & $\begin{array}{l}16.7 \% \\
1 \mathrm{~N}\end{array}$ & $\begin{array}{l}16.7 \% \\
1 \mathrm{~N}\end{array}$ & $\begin{array}{l}16.7 \% \\
1 \mathrm{~N}\end{array}$ \\
\hline$>10$ & $\begin{array}{l}5.6 \% \\
1 \mathrm{~N}\end{array}$ & $\begin{array}{l}55.6 \% \\
9 \mathrm{~N}+1 \mathrm{NP}\end{array}$ & $\begin{array}{l}27.8 \% \\
5 \mathrm{~N}\end{array}$ & $\begin{array}{l}11 \% \\
2 \mathrm{~N}\end{array}$ & \\
\hline \multicolumn{6}{|l|}{$\begin{array}{l}\text { Skin } \\
\text { Problems }\end{array}$} \\
\hline $1-5$ & & $\begin{array}{l}80 \% \\
3 \mathrm{~N}+1 \mathrm{NP}\end{array}$ & & & $\begin{array}{l}20 \% \\
1 \mathrm{NP}\end{array}$ \\
\hline $6-10$ & & $\begin{array}{l}50 \% \\
2 \mathrm{~N}+1 \mathrm{NP}\end{array}$ & $\begin{array}{l}33.3 \% \\
2 \mathrm{~N}\end{array}$ & $\begin{array}{l}16.7 \% \\
1 \mathrm{~N}\end{array}$ & \\
\hline$>10$ & $\begin{array}{l}11.1 \% \\
1 \mathrm{NP}\end{array}$ & $\begin{array}{l}55.6 \% \\
10 \mathrm{~N}\end{array}$ & $\begin{array}{l}27.8 \% \\
5 \mathrm{~N}\end{array}$ & $\begin{array}{l}5.5 \% \\
1 \mathrm{~N}\end{array}$ & \\
\hline
\end{tabular}




\begin{tabular}{|c|c|c|c|c|c|}
\hline $\begin{array}{l}\text { Symptoms/Years } \\
\text { of Experience }\end{array}$ & $\begin{array}{l}\text { Strongly } \\
\text { Agree }\end{array}$ & Agree & $\begin{array}{l}\text { Neither } \\
\text { agree or } \\
\text { disagree }\end{array}$ & Disagree & $\begin{array}{l}\text { Strongly } \\
\text { Agree }\end{array}$ \\
\hline \multicolumn{6}{|l|}{ Fatigue } \\
\hline $1-5$ & $\begin{array}{l}20 \% \\
1 \mathrm{NP}\end{array}$ & $\begin{array}{l}60 \% \\
2 \mathrm{~N}+1 \mathrm{NP}\end{array}$ & $\begin{array}{l}20 \% \\
1 \mathrm{~N}\end{array}$ & & \\
\hline $6-10$ & & $\begin{array}{l}100 \% \\
5 \mathrm{~N}+1 \mathrm{NP}\end{array}$ & & & \\
\hline$>10$ & $\begin{array}{l}38.9 \% \\
6 \mathrm{~N}+1 \mathrm{NP}\end{array}$ & $\begin{array}{l}55.6 \% \\
10 \mathrm{~N} \\
\end{array}$ & $\begin{array}{l}5.5 \% \\
1 \mathrm{~N} \\
\end{array}$ & & \\
\hline \multicolumn{6}{|l|}{ Breathlessness } \\
\hline $1-5$ & & $\begin{array}{l}80 \% \\
3 \mathrm{~N}+1 \mathrm{NP}\end{array}$ & & & $\begin{array}{l}20 \% \\
1 \mathrm{NP}\end{array}$ \\
\hline $6-10$ & & $\begin{array}{l}50 \% \\
2 \mathrm{~N}+1 \mathrm{NP}\end{array}$ & $\begin{array}{l}33.3 \% \\
2 \mathrm{~N} \\
\end{array}$ & $\begin{array}{l}16.7 \% \\
1 \mathrm{~N} \\
\end{array}$ & \\
\hline$>10$ & $\begin{array}{l}22 \% \\
3 \mathrm{~N}+1 \mathrm{NP}\end{array}$ & $\begin{array}{l}50 \% \\
9 \mathrm{~N}\end{array}$ & $\begin{array}{l}27.8 \% \\
5 \mathrm{~N}\end{array}$ & & \\
\hline \multicolumn{6}{|l|}{ Weight Gain } \\
\hline $1-5$ & & $\begin{array}{l}40 \% \\
1 \mathrm{~N}+1 \mathrm{NP}\end{array}$ & $\begin{array}{l}20 \% \\
1 \mathrm{~N}\end{array}$ & $\begin{array}{l}20 \% \\
1 \mathrm{~N}\end{array}$ & $\begin{array}{l}20 \% \\
1 \mathrm{~N}\end{array}$ \\
\hline $6-10$ & & $\begin{array}{l}16.7 \% \\
1 \mathrm{NP} \\
\end{array}$ & $\begin{array}{l}66.6 \% \\
4 \mathrm{~N} \\
\end{array}$ & $\begin{array}{l}16.7 \% \\
1 \mathrm{~N} \\
\end{array}$ & \\
\hline$>10$ & $\begin{array}{l}16.7 \% \\
2 \mathrm{~N}+1 \mathrm{NP}\end{array}$ & $\begin{array}{l}50 \% \\
9 \mathrm{~N} \\
\end{array}$ & $\begin{array}{l}27.8 \% \\
5 \mathrm{~N} \\
\end{array}$ & $\begin{array}{l}5.5 \% \\
1 \mathrm{~N} \\
\end{array}$ & \\
\hline \multicolumn{6}{|l|}{$\begin{array}{l}\text { Limb } \\
\text { MobilityIssues }\end{array}$} \\
\hline $1-5$ & & $\begin{array}{l}20 \% \\
1 \mathrm{NP}\end{array}$ & $\begin{array}{l}40 \% \\
2 \mathrm{~N} \\
\end{array}$ & $\begin{array}{l}20 \% \\
1 \mathrm{~N}\end{array}$ & $\begin{array}{l}20 \% \\
1 \mathrm{NP}\end{array}$ \\
\hline $6-10$ & & $\begin{array}{l}6.7 \% \\
1 \mathrm{NP} \\
\end{array}$ & $\begin{array}{l}33.3 \% \\
2 \mathrm{~N} \\
\end{array}$ & $\begin{array}{l}50 \% \\
3 \mathrm{~N} \\
\end{array}$ & \\
\hline$>10$ & $\begin{array}{l}16.7 \% \\
2 \mathrm{~N}+1 \mathrm{NP}\end{array}$ & $\begin{array}{l}33.3 \% \\
6 \mathrm{~N} \\
\end{array}$ & $\begin{array}{l}38.9 \% \\
7 \mathrm{~N} \\
\end{array}$ & $\begin{array}{l}11.1 \% \\
2 \mathrm{~N}\end{array}$ & \\
\hline \multicolumn{6}{|l|}{$\begin{array}{l}\text { Sleep } \\
\text { Problems }\end{array}$} \\
\hline $1-5$ & & $\begin{array}{l}60 \% \\
2 \mathrm{~N}+1 \mathrm{NP}\end{array}$ & $\begin{array}{l}20 \% \\
1 \mathrm{~N} \\
\end{array}$ & & $\begin{array}{l}20 \% \\
1 \mathrm{NP} \\
\end{array}$ \\
\hline $6-10$ & & $\begin{array}{l}33.3 \% \\
1 \mathrm{~N}+1 \mathrm{NP}\end{array}$ & $\begin{array}{l}50 \% \\
3 \mathrm{~N} \\
\end{array}$ & $\begin{array}{l}16.7 \% \\
1 \mathrm{~N} \\
\end{array}$ & \\
\hline$>10$ & $\begin{array}{l}11.8 \% \\
1 \mathrm{~N}+1 \mathrm{NP}\end{array}$ & $\begin{array}{l}58.8 \% \\
10 \mathrm{~N}\end{array}$ & $\begin{array}{l}29.4 \% \\
5 \mathrm{~N}\end{array}$ & & \\
\hline
\end{tabular}




\begin{tabular}{|c|c|c|c|c|c|}
\hline $\begin{array}{l}\text { Symptoms/Years } \\
\text { of experience }\end{array}$ & $\begin{array}{l}\text { Strongly } \\
\text { Agree }\end{array}$ & Agree & $\begin{array}{l}\text { Neither } \\
\text { agree or } \\
\text { disagree }\end{array}$ & Disagree & $\begin{array}{l}\text { Strongly } \\
\text { Disagree }\end{array}$ \\
\hline \multicolumn{6}{|l|}{ Loss of Libido } \\
\hline $1-5$ & & & $\begin{array}{l}60 \% \\
2 \mathrm{~N}+1 \mathrm{NP}\end{array}$ & $\begin{array}{l}20 \% \\
1 \mathrm{~N}\end{array}$ & $\begin{array}{l}20 \% \\
1 \mathrm{NP}\end{array}$ \\
\hline $6-10$ & & $\begin{array}{l}20 \% \\
1 \mathrm{~N}\end{array}$ & $\begin{array}{l}20 \% \\
1 \mathrm{~N}\end{array}$ & $\begin{array}{l}40 \% \\
2 \mathrm{~N}+1 \mathrm{NP}\end{array}$ & $\begin{array}{l}20 \% \\
1 \mathrm{~N}\end{array}$ \\
\hline$>10$ & $\begin{array}{l}5.6 \% \\
1 \mathrm{NP}\end{array}$ & $\begin{array}{l}27.8 \% \\
5 \mathrm{~N}\end{array}$ & $\begin{array}{l}55.6 \% \\
10 \mathrm{~N}\end{array}$ & $\begin{array}{l}11.1 \% \\
2 \mathrm{~N}\end{array}$ & \\
\hline \multicolumn{6}{|l|}{$\begin{array}{l}\text { Sexual } \\
\text { Dysfunction }\end{array}$} \\
\hline $1-5$ & & & $\begin{array}{l}60 \% \\
2 \mathrm{~N}+1 \mathrm{NP} \\
\end{array}$ & $\begin{array}{l}20 \% \\
1 \mathrm{~N} \\
\end{array}$ & $\begin{array}{l}20 \% \\
1 \mathrm{NP} \\
\end{array}$ \\
\hline $6-10$ & & $\begin{array}{l}16.7 \% \\
1 \mathrm{~N}\end{array}$ & $\begin{array}{l}16.7 \% \\
1 \mathrm{~N}\end{array}$ & $\begin{array}{l}50 \% \\
2 \mathrm{~N}+1 \mathrm{NP}\end{array}$ & $\begin{array}{l}16.7 \% \\
1 \mathrm{~N}\end{array}$ \\
\hline$>10$ & & $\begin{array}{l}18.75 \% \\
2 \mathrm{~N}+1 \mathrm{NP} \\
\end{array}$ & $\begin{array}{l}56.25 \% \\
9 \mathrm{~N} \\
\end{array}$ & $\begin{array}{l}25 \% \\
4 \mathrm{~N} \\
\end{array}$ & \\
\hline \multicolumn{6}{|l|}{$\begin{array}{l}\text { Bowel and } \\
\text { Urinary } \\
\text { Problems }\end{array}$} \\
\hline $1-5$ & $\begin{array}{l}20 \% \\
1 \mathrm{NP}\end{array}$ & $\begin{array}{l}60 \% \\
2 \mathrm{~N}+1 \mathrm{NP}\end{array}$ & & $\begin{array}{l}20 \% \\
1 \mathrm{~N}\end{array}$ & \\
\hline $6-10$ & & $\begin{array}{l}50 \% \\
2 \mathrm{~N}\end{array}$ & $\begin{array}{l}33.3 \% \\
1 \mathrm{~N}+1 \mathrm{NP}\end{array}$ & $\begin{array}{l}16.7 \% \\
1 \mathrm{~N}\end{array}$ & \\
\hline$>10$ & $\begin{array}{l}33.3 \% \\
5 \mathrm{~N}+1 \mathrm{NP} \\
\end{array}$ & $\begin{array}{l}55.6 \% \\
10 \mathrm{~N}\end{array}$ & $\begin{array}{l}5.5 \% \\
1 \mathrm{~N} \\
\end{array}$ & $\begin{array}{l}5.5 \% \\
1 \mathrm{~N}\end{array}$ & \\
\hline \multicolumn{6}{|l|}{$\begin{array}{l}\text { Nausea and } \\
\text { Vomiting }\end{array}$} \\
\hline $1-5$ & $\begin{array}{l}20 \% \\
1 \mathrm{NP}\end{array}$ & $\begin{array}{l}80 \% \\
3 \mathrm{~N}+1 \mathrm{NP}\end{array}$ & & & \\
\hline $6-10$ & $\begin{array}{l}16.7 \% \\
1 \mathrm{NP}\end{array}$ & $\begin{array}{l}83.3 \% \\
5 \mathrm{~N}\end{array}$ & & & \\
\hline$>10$ & $\begin{array}{l}38.9 \% \\
6 \mathrm{~N}+1 \mathrm{NP}\end{array}$ & $\begin{array}{l}55.6 \% \\
10 \mathrm{~N}\end{array}$ & $\begin{array}{l}5.5 \% \\
1 \mathrm{~N}\end{array}$ & & \\
\hline
\end{tabular}




\begin{tabular}{|c|c|c|c|c|c|}
\hline $\begin{array}{l}\text { Symptoms/Years of } \\
\text { experience }\end{array}$ & $\begin{array}{l}\text { Strongly } \\
\text { Agree }\end{array}$ & Agree & $\begin{array}{l}\text { Neither } \\
\text { agree or } \\
\text { disagree }\end{array}$ & Disagree & $\begin{array}{l}\text { Strongly } \\
\text { Disagree }\end{array}$ \\
\hline \multicolumn{6}{|l|}{ Fertility Issues } \\
\hline $1-5$ & & $\begin{array}{l}20 \% \\
1 \mathrm{~N}\end{array}$ & $\begin{array}{l}20 \% \\
1 \mathrm{~N}\end{array}$ & $\begin{array}{l}20 \% \\
1 \mathrm{~N}\end{array}$ & $\begin{array}{l}40 \% \\
1 \mathrm{~N}+1 \mathrm{NP}\end{array}$ \\
\hline 6-10 & $\begin{array}{l}16.7 \% \\
1 \mathrm{NP}\end{array}$ & $\begin{array}{l}16.7 \% \\
1 \mathrm{~N}\end{array}$ & & $\begin{array}{l}50 \% \\
3 \mathrm{~N}\end{array}$ & $\begin{array}{l}16.7 \% \\
1 \mathrm{~N}\end{array}$ \\
\hline$>10$ & & $\begin{array}{l}22.2 \% \\
4 \mathrm{~N}\end{array}$ & $\begin{array}{l}55.6 \% \\
9 \mathrm{~N}+1 \mathrm{NP}\end{array}$ & $\begin{array}{l}22.2 \% \\
4 \mathrm{~N}\end{array}$ & \\
\hline \multicolumn{6}{|l|}{ Hot Flashes } \\
\hline $1-5$ & & $\begin{array}{l}60 \% \\
2 \mathrm{~N}+1 \mathrm{NP}\end{array}$ & & $\begin{array}{l}20 \% \\
1 \mathrm{~N}\end{array}$ & $\begin{array}{l}20 \% \\
1 \mathrm{NP}\end{array}$ \\
\hline 6-10 & & $\begin{array}{l}33.3 \% \\
1 \mathrm{~N}+1 \mathrm{NP}\end{array}$ & & $\begin{array}{l}50 \% \\
3 \mathrm{~N}\end{array}$ & $\begin{array}{l}16.7 \% \\
1 \mathrm{~N}\end{array}$ \\
\hline$>10$ & $\begin{array}{l}16.7 \% \\
2 \mathrm{~N}+1 \mathrm{NP}\end{array}$ & $\begin{array}{l}22.2 \% \\
4 \mathrm{~N}\end{array}$ & $\begin{array}{l}50 \% \\
9 \mathrm{~N}\end{array}$ & $\begin{array}{l}11.1 \% \\
2 \mathrm{~N}\end{array}$ & \\
\hline \multicolumn{6}{|l|}{$\begin{array}{l}\text { Menopausal } \\
\text { Concerns }\end{array}$} \\
\hline $1-5$ & & $\begin{array}{l}20 \% \\
1 \mathrm{NP}\end{array}$ & $\begin{array}{l}20 \% \\
1 \mathrm{~N}\end{array}$ & $\begin{array}{l}40 \% \\
2 \mathrm{~N}\end{array}$ & $\begin{array}{l}20 \% \\
1 \mathrm{NP}\end{array}$ \\
\hline 6-10 & & $\begin{array}{l}33.3 \% \\
1 \mathrm{~N}+1 \mathrm{NP}\end{array}$ & $\begin{array}{l}16.7 \% \\
1 \mathrm{~N}\end{array}$ & $\begin{array}{l}50 \% \\
3 \mathrm{~N} \\
\end{array}$ & \\
\hline$>10$ & $\begin{array}{l}11.1 \% \\
2 \mathrm{~N}\end{array}$ & $\begin{array}{l}11.1 \% \\
2 \mathrm{~N}\end{array}$ & $\begin{array}{l}66.7 \% \\
11 \mathrm{~N}+1 \mathrm{NP}\end{array}$ & $\begin{array}{l}11.1 \% \\
2 \mathrm{~N}\end{array}$ & \\
\hline \multicolumn{6}{|c|}{ Anxiety/Depression } \\
\hline $1-5$ & & $\begin{array}{l}80 \% \\
3 \mathrm{~N}+1 \mathrm{NP}\end{array}$ & & & $\begin{array}{l}20 \% \\
1 \mathrm{NP}\end{array}$ \\
\hline $6-10$ & & $\begin{array}{l}83.3 \% \\
4 \mathrm{~N}+1 \mathrm{NP}\end{array}$ & & $\begin{array}{l}16.7 \% \\
1 \mathrm{~N}\end{array}$ & \\
\hline$>10$ & $\begin{array}{l}16.7 \% \\
3 \mathrm{~N}\end{array}$ & $\begin{array}{l}50 \% \\
8 \mathrm{~N}+1 \mathrm{NP}\end{array}$ & $\begin{array}{l}27.8 \% \\
5 \mathrm{~N}\end{array}$ & $\begin{array}{l}5.5 \% \\
1 \mathrm{~N}\end{array}$ & \\
\hline \multicolumn{6}{|c|}{ Memory Problems } \\
\hline $1-5$ & & $\begin{array}{l}20 \% \\
1 \mathrm{NP}\end{array}$ & $\begin{array}{l}40 \% \\
2 \mathrm{~N}\end{array}$ & $\begin{array}{l}20 \% \\
1 \mathrm{~N}\end{array}$ & $\begin{array}{l}20 \% \\
1 \mathrm{NP}\end{array}$ \\
\hline $6-10$ & & $\begin{array}{l}16.7 \% \\
1 \mathrm{~N}\end{array}$ & & $\begin{array}{l}83.3 \% \\
4 \mathrm{~N}+1 \mathrm{NP}\end{array}$ & \\
\hline$>10$ & $\begin{array}{l}5.6 \% \\
1 \mathrm{~N}\end{array}$ & $\begin{array}{l}33.3 \% \\
5 \mathrm{~N}+1 \mathrm{NP}\end{array}$ & $\begin{array}{l}44.4 \% \\
8 \mathrm{~N}\end{array}$ & $\begin{array}{l}16.7 \% \\
3 \mathrm{~N}\end{array}$ & \\
\hline
\end{tabular}




\begin{tabular}{|c|c|c|c|c|c|}
\hline $\begin{array}{l}\text { Symptoms/Years } \\
\text { of experience }\end{array}$ & $\begin{array}{l}\text { Strongly } \\
\text { Agree }\end{array}$ & Agree & $\begin{array}{l}\text { Neither } \\
\text { agree or } \\
\text { disagree }\end{array}$ & Disagree & $\begin{array}{l}\text { Strongly } \\
\text { Disagree }\end{array}$ \\
\hline \multicolumn{6}{|l|}{$\begin{array}{l}\text { Cardiac } \\
\text { Effects }\end{array}$} \\
\hline $1-5$ & & $\begin{array}{l}75 \% \\
2 N+1 N P\end{array}$ & & & $\begin{array}{l}25 \% \\
1 N P \\
\end{array}$ \\
\hline $6-10$ & & $\begin{array}{l}50 \% \\
3 \mathrm{~N} \\
\end{array}$ & & $\begin{array}{l}33.3 \% \\
1 N+1 N P\end{array}$ & $\begin{array}{l}16.7 \% \\
1 \mathrm{~N} \\
\end{array}$ \\
\hline$>10$ & $\begin{array}{l}11.1 \% \\
2 \mathrm{~N}\end{array}$ & $\begin{array}{l}16.7 \% \\
3 \mathrm{~N}\end{array}$ & $\begin{array}{l}61.1 \% \\
10 N+1 N P\end{array}$ & $\begin{array}{l}11.1 \% \\
2 \mathrm{~N}\end{array}$ & \\
\hline \multicolumn{6}{|l|}{ Neuropathy } \\
\hline $1-5$ & & $\begin{array}{l}100 \% \\
2 N+2 N P\end{array}$ & & & \\
\hline $6-10$ & $\begin{array}{l}16.7 \% \\
1 \mathrm{~N} \\
\end{array}$ & $\begin{array}{l}50 \% \\
2 N+1 N P\end{array}$ & $\begin{array}{l}33.3 \% \\
2 \mathrm{~N} \\
\end{array}$ & & \\
\hline$>10$ & $\begin{array}{l}16.7 \% \\
3 \mathrm{~N}\end{array}$ & $\begin{array}{l}61.1 \% \\
10 N+1 N P\end{array}$ & $\begin{array}{l}22.2 \% \\
4 \mathrm{~N}\end{array}$ & & \\
\hline
\end{tabular}




\section{Table 3}

\section{Specific tasks with care coordination, proactive care, and surveillance}

\section{How Easy Or Difficult It is for you to Manage Those Individuals Who Have}

\section{Received Cancer Treatment. $(1=$ easy to $10=$ difficult $)$}

$\mathrm{N}=29 \quad$ Nurses $=25 \quad$ Nurse Practitioners $=4 \quad(\mathrm{~N}=$ Nurse $\quad \mathrm{NP}=$ Nurse Practitioner $)$

Recognize the symptoms associated with late effects of cancer treatment?

\begin{tabular}{|l|l|l|l|l|l|l|l|l|l|}
\hline $\mathbf{1}$ & $\mathbf{2}$ & $\mathbf{3}$ & $\mathbf{4}$ & $\mathbf{5}$ & $\mathbf{6}$ & $\mathbf{7}$ & $\mathbf{8}$ & $\mathbf{9}$ & $\mathbf{1 0}$ \\
\hline $\mathrm{N} 5+2 \mathrm{NP}$ & $\mathrm{N} 3+1 \mathrm{NP}$ & $\mathrm{N} 4$ & $\mathrm{~N} 3$ & $\mathrm{~N} 6$ & $\mathrm{~N} 2$ & $\mathrm{~N} 2$ & $\mathrm{NP} 1$ & & \\
$24.1 \%$ & $13.8 \%$ & $13.8 \%$ & $10.3 \%$ & $20.7 \%$ & $6.9 \%$ & $6.9 \%$ & $3.4 \%$ & $0.0 \%$ & $0.0 \%$ \\
\hline
\end{tabular}

Recognize the psychological and social problems associated with long term cancer survivorship?

\begin{tabular}{|l|l|l|l|l|l|l|l|l|l|}
\hline $\mathbf{1}$ & $\mathbf{2}$ & $\mathbf{3}$ & $\mathbf{4}$ & $\mathbf{5}$ & $\mathbf{6}$ & $\mathbf{7}$ & $\mathbf{8}$ & $\mathbf{9}$ & $\mathbf{1 0}$ \\
\hline $\mathrm{N} 4+2 \mathrm{NP}$ & $\mathrm{N} 3+2 \mathrm{NP}$ & $\mathrm{N} 7$ & $\mathrm{~N} 3$ & $\mathrm{~N} 4$ & $\mathrm{~N} 2$ & $\mathrm{~N} 2$ & & & \\
$20.7 \%$ & $17.2 \%$ & $24.1 \%$ & $10.3 \%$ & $13.8 \%$ & $6.9 \%$ & $6.9 \%$ & $0.0 \%$ & $0.0 \%$ & $0.0 \%$ \\
\hline
\end{tabular}

Inform and discuss potential long-term health effects with patients?

\begin{tabular}{|l|l|l|l|l|l|l|l|l|l|}
\hline $\mathbf{1}$ & $\mathbf{2}$ & $\mathbf{3}$ & $\mathbf{4}$ & $\mathbf{5}$ & $\mathbf{6}$ & $\mathbf{7}$ & $\mathbf{8}$ & $\mathbf{9}$ & $\mathbf{1 0}$ \\
\hline $\mathrm{N} 3+3 \mathrm{NP}$ & $\mathrm{N} 1$ & $\mathrm{~N} 8$ & $\mathrm{~N} 3$ & $\mathrm{~N} 5$ & $\mathrm{~N} 4$ & $\mathrm{~N} 1+1 \mathrm{NP}$ & & & \\
$20.7 \%$ & $1.34 \%$ & $27.6 \%$ & $10.3 \%$ & $17.2 \%$ & $13.8 \%$ & $6.9 \%$ & $0.0 \%$ & $0.0 \%$ & $0.0 \%$ \\
\hline
\end{tabular}




\section{Nurse Practitioners Practice of Care}

$\mathrm{NP}=$ Nurse Practitioner

Do you provide a survivorship care plan to a cancer patient after treatment?

$\mathrm{NP}=4 \quad$ Yes $100 \%$

$(1=$ easy to $10=$ difficult $)$

Provide symptom management to mild to moderate side effects of cancer treatment?

\begin{tabular}{|l|l|l|l|l|l|l|l|l|l|}
\hline $\mathbf{1}$ & $\mathbf{2}$ & $\mathbf{3}$ & $\mathbf{4}$ & $\mathbf{5}$ & $\mathbf{6}$ & $\mathbf{7}$ & $\mathbf{8}$ & $\mathbf{9}$ & $\mathbf{1 0}$ \\
\hline NP 2 & NP 1 & & & & NP 1 & & & & \\
$50 \%$ & $25 \%$ & & & & $25 \%$ & & & & \\
\hline
\end{tabular}

Provide complex symptom management for severe symptoms as a result of cancer and its treatment?

$(\mathrm{NP}=3 \quad 1$ omission $)$

\begin{tabular}{|l|l|l|l|l|l|l|l|l|l|}
\hline $\mathbf{1}$ & $\mathbf{2}$ & $\mathbf{3}$ & $\mathbf{4}$ & $\mathbf{5}$ & $\mathbf{6}$ & $\mathbf{7}$ & $\mathbf{8}$ & $\mathbf{9}$ & $\mathbf{1 0}$ \\
\hline NP1 & NP1 & & & & NP1 & & & & \\
$33.3 \%$ & $33.3 \%$ & & & & $33.3 \%$ & & & & \\
\hline
\end{tabular}

Independently review and assess patients on their potential effects?

\begin{tabular}{|l|l|l|l|l|l|l|l|l|l|}
\hline $\mathbf{1}$ & $\mathbf{2}$ & $\mathbf{3}$ & $\mathbf{4}$ & $\mathbf{5}$ & $\mathbf{6}$ & $\mathbf{7}$ & $\mathbf{8}$ & $\mathbf{9}$ & $\mathbf{1 0}$ \\
\hline NP 3 & & NP 1 & & & & & & & \\
$75 \%$ & & $25 \%$ & & & & & & & \\
\hline
\end{tabular}

Review medications and to advise patients on their potential effects

\begin{tabular}{|l|l|l|l|l|l|l|l|l|l|}
\hline $\mathbf{1}$ & $\mathbf{2}$ & $\mathbf{3}$ & $\mathbf{4}$ & $\mathbf{5}$ & $\mathbf{6}$ & $\mathbf{7}$ & $\mathbf{8}$ & $\mathbf{9}$ & $\mathbf{1 0}$ \\
\hline NP 3 & & NP 1 & & & & & & & \\
$75 \%$ & & $25 \%$ & & & & & & & \\
\hline
\end{tabular}


Refer patient to the multi-disciplinary team?

\begin{tabular}{|l|l|l|l|l|l|l|l|l|l|}
\hline $\mathbf{1}$ & $\mathbf{2}$ & $\mathbf{3}$ & $\mathbf{4}$ & $\mathbf{5}$ & $\mathbf{6}$ & $\mathbf{7}$ & $\mathbf{8}$ & $\mathbf{9}$ & $\mathbf{1 0}$ \\
\hline NP 4 & & & & & & & & & \\
$100 \%$ & & & & & & & & & \\
\hline
\end{tabular}

Effectively teach self-management and self-monitoring for cancer patients post-therapy?

\begin{tabular}{|l|l|l|l|l|l|l|l|l|l|}
\hline $\mathbf{1}$ & $\mathbf{2}$ & $\mathbf{3}$ & $\mathbf{4}$ & $\mathbf{5}$ & $\mathbf{6}$ & $\mathbf{7}$ & $\mathbf{8}$ & $\mathbf{9}$ & $\mathbf{1 0}$ \\
\hline NP 3 & & & & & & & NP 1 & & \\
$75 \%$ & & & & & & & $25 \%$ & & \\
\hline
\end{tabular}

Create an individualized long-term plan of care for recovery and wellbeing?

\begin{tabular}{|l|l|l|l|l|l|l|l|l|l|}
\hline $\mathbf{1}$ & $\mathbf{2}$ & $\mathbf{3}$ & $\mathbf{4}$ & $\mathbf{5}$ & $\mathbf{6}$ & $\mathbf{7}$ & $\mathbf{8}$ & $\mathbf{9}$ & $\mathbf{1 0}$ \\
\hline NP 4 & & & & & & & & & \\
$100 \%$ & & & & & & & & & \\
\hline
\end{tabular}

Recognize the potential late-effects of my client group?

\begin{tabular}{|l|l|l|l|l|l|l|l|l|l|}
\hline $\mathbf{1}$ & $\mathbf{2}$ & $\mathbf{3}$ & $\mathbf{4}$ & $\mathbf{5}$ & $\mathbf{6}$ & $\mathbf{7}$ & $\mathbf{8}$ & $\mathbf{9}$ & $\mathbf{1 0}$ \\
\hline NP 3 & & & & & & & & & NP 1 \\
$75 \%$ & & & & & & & & & $25 \%$ \\
\hline
\end{tabular}




\section{Table 4}

Which areas of cancer care would you like to know more about to help manage patient care:

Check Yes or No $\quad \mathrm{N}=(29) \quad$ Nurse $=25 \quad$ Nurse Practitioner $=4$

\begin{tabular}{|c|c|c|}
\hline & Yes & No \\
\hline $\begin{array}{l}\text { Knowledge of long term } \\
\text { health effects of cancer } \\
\text { treatment }\end{array}$ & $86.2 \%$ & $13.8 \%$ \\
\hline $\begin{array}{l}\text { Endocrine effects of cancer } \\
\text { therapies }\end{array}$ & $87.2 \%$ & $10.3 \%$ \\
\hline $\begin{array}{l}\text { Prevention and } \\
\text { management of cancer } \\
\text { treatment-induced bone } \\
\text { loss and joint pain }\end{array}$ & $82.1 \%$ & $17.9 \%$ \\
\hline $\begin{array}{l}\text { Potential cardiac effects of } \\
\text { chemotherapies and } \\
\text { hormone therapies }\end{array}$ & $82.8 \%$ & $17.2 \%$ \\
\hline $\begin{array}{l}\text { Tests and investigations } \\
\text { required after cancer } \\
\text { therapy late-effects } \\
\text { surveillance }\end{array}$ & $79.3 \%$ & $20.7 \%$ \\
\hline $\begin{array}{l}\text { Medication management } \\
\text { and adherence }\end{array}$ & $78.6 \%$ & $21.4 \%$ \\
\hline $\begin{array}{l}\text { Managing psycho-social } \\
\text { aspects of long term cancer } \\
\text { survival }\end{array}$ & $75.0 \%$ & $25.0 \%$ \\
\hline $\begin{array}{l}\text { Assessment of sexual } \\
\text { dysfunction and fertility }\end{array}$ & $79.3 \%$ & $20.7 \%$ \\
\hline $\begin{array}{l}\text { Cancer surgeries and } \\
\text { subsequent effects on } \\
\text { physiological and } \\
\text { functional processes }\end{array}$ & $75.0 \%$ & $25.0 \%$ \\
\hline $\begin{array}{l}\text { Self- Management } \\
\text { Techniques }\end{array}$ & $72.4 \%$ & $27.6 \%$ \\
\hline
\end{tabular}




\begin{tabular}{|l|l|l|}
\hline & & \\
\hline & Yes & No \\
\hline Lifestyle activity & $65.5 \%$ & $31 \%$ \\
\hline Rehabilitation & $58.6 \%$ & $41.4 \%$ \\
\hline Exercise & $69.0 \%$ & $31.0 \%$ \\
\hline
\end{tabular}

